\title{
Early Inflammation in Muscular Dystrophy Differs between Limb and Respiratory Muscles and Increases with Dystrophic Severity
} Check for updates

Zachary M. Howard, ${ }^{*}$ Jeovanna Lowe, ${ }^{*}$ Anton J. Blatnik, $3^{\text {rd }},{ }^{\dagger}$ Deztani Roberts, ${ }^{*}$ Arthur H.M. Burghes, ${ }^{\dagger}$ Shyam S. Bansal, ${ }^{* \ddagger}$ and Jill A. Rafael-Fortney**

From the Departments of Physiology and Cell Biology* and Biological Chemistry and Pharmacology ${ }^{\dagger}$ and the Davis Heart and Lung Research Institute, ${ }^{\ddagger}$ College of Medicine, The Ohio State University, Columbus, Ohio

Accepted for publication

January 11, 2021.

Address correspondence to Jill A. Rafael-Fortney, Ph.D., Department of Physiology and Cell Biology, College of Medicine, The Ohio State University, 390 Biomedical Research Tower, 460 W. 12th Ave., Columbus, OH 43210; or Shyam S. Bansal, Ph.D., Department of Physiology and Cell Biology, College of Medicine, The Ohio State University, 607 Davis Heart and Lung Research Institute, $473 \mathrm{~W}$. 12th Ave., Columbus, $\mathrm{OH}$ 43210. E-mail: rafael-fortney.1@osu.edu or shyam.bansal@osumc.edu.

\begin{abstract}
Duchenne muscular dystrophy (DMD) is a genetic, degenerative, striated muscle disease exacerbated by chronic inflammation. Mdx mice in the genotypic DMD model poorly represent immune-mediated pathology observed in patients. Improved understanding of innate immunity in dystrophic muscles is required to develop specific anti-inflammatory treatments. Here, inflammation in $m d x$ mice and the more fibrotic utrn ${ }^{+/-} ; m d x$ Het model was comprehensively investigated. Unbiased analysis showed that $m d x$ and Het mice contain increased levels of numerous chemokines and cytokines, with further increased in Het mice. Chemokine and chemokine receptor gene expression levels were dramatically increased in 4-week-old dystrophic quadriceps muscles, and to a lesser extent in diaphragm during the early injury phase, and had a small but consistent increase at 8 and 20 weeks. An optimized direct immune cell isolation method prevented loss of up to $90 \%$ of macrophages with density-dependent centrifugation previously used for $m d x$ flow cytometry. Het quadriceps contain higher proportions of neutrophils and infiltrating monocytes than $\mathrm{mdx}$, and higher percentages of $\mathrm{F} 4 / 80^{\mathrm{Hi}}$, but lower percentages of $\mathrm{F} 4 / 80^{\mathrm{LO}}$ cells and patrolling monocytes compared with Het diaphragms. These differences may restrict regenerative potential of dystrophic diaphragms, increasing pathologic severity. Fibrotic and inflammatory gene expression levels are higher in myeloid cells isolated from Het compared with $m d x$ quadriceps, supporting Het mice may represent an improved model for testing therapeutic manipulation of inflammation in DMD. (Am J Pathol 2021, 191: 730-747; https://doi.org/10.1016/ j.ajpath.2021.01.008)
\end{abstract}

Duchenne muscular dystrophy (DMD), a degenerative disease of striated muscles, is caused by loss-of-function mutations in the dystrophin gene. Dystrophin-deficient myofibers lead to chronic injuries that diminish regenerative potential of limb and respiratory skeletal muscles, resulting in progressive fibrosis and loss of function into early adulthood. ${ }^{1}$ On injury, myofibers secrete cytokines and chemokines. ${ }^{2,3}$ These factors activate resident myoblasts, fibroblasts, endothelial cells, and immune cells in a paracrine manner, and amplify signals to also recruit immune cells from circulation. ${ }^{4,5}$ Continuous, adjacent myofiber injuries produce a chronic inflammatory state in the muscle, which appears to peak at 4 weeks of age in the genotypic $m d x$ mouse model of DMD and diminish to persistent, low-grade inflammation throughout the fibrotic phase. ${ }^{3,6}$ Although the $m d x$ mouse is the genotypic model of DMD, the disease is more severe in humans. $M d x$ mice haplo-insufficient for the partially compensating protein utrophin $\left(\right.$ utrn $^{+/-} ; m d x$; Het mice) develop significantly more inflammation and fibrosis; however, the specific immune cell and cytokine signaling differences between $m d x$ and Het mice have not been quantitatively compared. ${ }^{7}$ Identifying cytokine signaling and immune cells that

Supported by NIH grants R01 AR072574 (J.A.R.-F.), T32 HL134616 (J.A.R.-F. and Z.M.H.), and R00 HL132123 (S.S.B.).

S.S.B. and J.A.R.-F. contributed equally to this work.

Disclosures: None declared. 
underly increasing dystrophic severity is critical for developing new treatment strategies. Prednisone, an antiinflammatory drug that is the standard of care for DMD patients, provides modest improvements in muscle strength. ${ }^{8}$ Severe side effects accompany the benefits of long-term prednisone usage and necessitate development of alternative immunomodulatory therapies.

Innate myeloid and adaptive lymphoid immune responses are required for efficient tissue regeneration across various organs, injuries, and diseases. ${ }^{9}$ In normal skeletal muscle, similar to other highly regenerative organs, resident immune cells such as macrophages and dendritic cells contribute to the regenerative potential conferred by muscle stem cells. ${ }^{10,11}$ Resident macrophages in healthy mouse skeletal muscle are replaced continuously throughout the animal's lifespan by blood monocytes. ${ }^{12}$ Inflammation in dystrophic skeletal muscle is composed of myeloid and lymphoid cells, with myeloid cells found to be more abundant. ${ }^{13,14} \mathrm{Neu}$ trophils, monocytes, and macrophages are a heterogeneous group of myeloid immune cells that accelerate myofiber necrosis and fibrosis in DMD patients and mouse models. ${ }^{15}$ Neutrophils and monocytes, the first responders to muscle damage, are required for the initial phases of regeneration, but can cause further tissue damage if their response is exacerbated. ${ }^{16-18}$ Monocytes differentiate into macrophages, dendritic cells, or fibrocytes, depending on the genetic predisposition of that monocyte, as well as the cytokines and chemokines it encounters. ${ }^{19-21}$ Monocytes have also been shown to enter tissues and perform functions without immediately differentiating into one of the described cell types. ${ }^{22}$

The contributions of macrophages to dystrophic pathology are incredibly nuanced; subtypes of macrophages, including M1, M2a, M2b, and M2c, have varied, often conflicting functions and distributions that are temporally regulated. ${ }^{23-25}$ Myoblasts in the injury site are stimulated to replace or repair damaged myofibers by M1-like macrophages. ${ }^{26}$ As necrotic debris is cleared by immune cells and myoblasts differentiate, immunosuppressive M2-like CD206-positive macrophages that suppress the inflammation and conclude regeneration become more prevalent. ${ }^{27-29}$ Macrophages present degraded self-antigens to infiltrating lymphocytes to assist in concluding regeneration. Advancements in understanding macrophage phenotypes, particularly in heart disease, have emphasized a reclassification of these populations using markers that are representative of cell function and origin, including major histocompatibility complex II (MHC II) and CCR2. ${ }^{30-32}$

In this study, we use a comprehensive approach to define the inflammatory signatures underlying the differences in severity observed in the $m d x$ and Het mouse models by comparing muscle cytokine protein levels and cytokine receptor gene expression levels together with flow cytometric analysis of immune cell populations. Flow cytometric analyses leverage prior immunohistochemistry and flow immune cell markers and incorporate functional markers and an unbiased isolation technique to provide a thorough understanding of early inflammation that leads to ultimate quantitative differences in fibrosis.

\section{Materials and Methods}

\section{Mouse Breeding and Handling}

Animal protocols were approved by the Institutional Animal Care and Use Committee of The Ohio State University (Columbus, $\mathrm{OH}$ ), which is in compliance with the laws of the United States of America and conforms to the NIH Guide for the Care and Use of Laboratory Animals ${ }^{33}$. Wildtype C57BL/10 (C57), $m d x$, and Het $\left(m d x / u t r n^{+/-}\right)$mice were bred and euthanized for tissue harvesting at 4,8 , and 20 weeks of age for all RNA, protein, and cell-based assays performed in this study. All $m d x$ and Het mice were derived from the same colony and were on a C57BL/10 background. Het mice were genotyped, as previously described. ${ }^{34}$

\section{Tissue Homogenization and Mouse Cytokine Proteome Profiler}

Four-week-old C57BL/10 $[n=2$ male (M) and 1 female (F)], $m d x(n=3 \mathrm{M}$ and $2 \mathrm{~F})$, and Het $(n=2 \mathrm{M}$ and $3 \mathrm{~F}) \mathrm{LN}_{2}$ flash-frozen quadriceps were homogenized in lysis buffer composed of $1 \%$ Triton X-100 (Sigma, St. Louis, MO; T9284) in Dulbecco's phosphate-buffered saline (Thermo Fischer, Waltham, MA; 14190-144), containing $10 \mu \mathrm{g} / \mathrm{mL}$ aprotinin (Sigma; A1153), leupeptin (Sigma; L2884), and pepstatin A (Sigma; P5318) on ice. Following homogenization, samples were flash frozen and thawed on ice. Centrifugation was performed at $10,000 \times g$ for 5 minutes $\left(4^{\circ} \mathrm{C}\right)$, and supernatants from the same genotype were pooled for analysis. Protein concentrations were determined using the $D C$ protein assay (Bio-Rad Laboratories, Hercules, CA; 5000166). Separate membranes from the Proteome Profiler Mouse Cytokine Array Kit A (R\&D Systems, Minneapolis, MN; ARY006) were incubated with $5 \mathrm{mg}$ of protein from each genotype. The assay was performed according to the manufacturer's instructions and detected using blue X-ray film (GeneMate Kaysville, UT; F90298X10). Relative cytokine levels were quantified using HL Image++ Quick Spots Tool version 25.0.0r (Western Vision Software, Salt Lake City, UT). Cytokines that were undetectable in C57 were not quantified and are not included in the data presented.

\section{Tissue RNA Extraction, Purification, and Real-Time Quantitative RT-PCR}

Four-week-old $(n: \mathrm{C} 57=2 \mathrm{M}$ and $1 \mathrm{~F} ; m d x=3 \mathrm{M}$ and $2 \mathrm{~F}$; Het $=2 \mathrm{M}$ and $3 \mathrm{~F}), 8$-week-old $(n: \mathrm{C} 57=1 \mathrm{M}$ and $2 \mathrm{~F}$; $m d x=3 \mathrm{M}$ and $2 \mathrm{~F}$; Het $=4 \mathrm{M}$ and $1 \mathrm{~F}$ ), and 20-week-old ( $n$ : $\mathrm{C} 57=1 \mathrm{M}$ and $2 \mathrm{~F} ; m d x=3 \mathrm{M}$ and $2 \mathrm{~F} ; \mathrm{Het}=4 \mathrm{M}$ and 1F) $\mathrm{C} 57, m d x$, and Het $\mathrm{LN}_{2}$ flash-frozen quadriceps and 
diaphragms were homogenized in TRIzol reagent (Thermo Fisher;15596026) on ice. Extraction of RNA was performed according to the manufacturer's instructions and DNased using RQ1 DNase (Promega, Madison, WI; M6101). Purified RNA was reverse transcribed into cDNA using a highcapacity cDNA synthesis kit (Thermo Fisher; 4368814). Reaction efficiency was checked qualitatively utilizing RT-PCR for the endogenous control gene (Actb) before realtime quantitative RT-PCR. Real-time quantitative RT-PCR analysis was performed on cDNA derived from whole skeletal muscle. The list of transcripts and the corresponding primer sequences are listed in Table 1 (primers were acquired from Thermo Fisher).

\section{Histology}

Four-week-old, 8-week-old, and 20-week-old $m d x$ and Het quadriceps and diaphragms $(n=3 \mathrm{M})$ were embedded in OCT compound, frozen in $\mathrm{LN}_{2}$-cooled isopentane, and sectioned on a cryostat (Bright, Huntingdon, UK). One 20-week-old C57 was used as a control. Frozen sections were hematoxylin and eosin-stained and imaged on a Nikon Eclipse 800 microscope using a Nikon DS-Ri2 Digital camera driven by Nikon Br Elements software.

\section{Skeletal Muscle Digestion, Generation of Single-Cell} Suspensions, and Density-Dependent Centrifugation

Four-week-old C57BL/10 $(n=6 \mathrm{M}), m d x(n=3 \mathrm{M}$ and $3 \mathrm{~F})$, and Het $(n=3 \mathrm{M}$ and $3 \mathrm{~F})$ mice were euthanized via cervical dislocation, and quadriceps and diaphragms were harvested, rinsed in cold Dulbecco's phosphate-buffered saline without $\mathrm{CaCl}_{2}$ or $\mathrm{MgCl}_{2}$ (Thermo Fisher; A1285601), and weighed. Tissues were finely minced with a razor blade and incubated in $10 \mathrm{~mL} / \mathrm{g}$ digestion buffer (Dulbecco's modified Eagle's medium; Thermo Fisher; 21013024; 0.02\% Collagenase P;
Sigma; $11213857001 ; 0.1 \%$ RQ1 DNase) at $37^{\circ} \mathrm{C}$ for 30 minutes. The digested tissues were triturated using a $5-\mathrm{mL}$ pipet coated in fetal bovine serum (R\&D; S11150), and 3 $\mathrm{mL}$ of autoMACS Running Buffer (Miltenyi Biotec, Bergisch Gladbach, Germany; 130091221) was added to quench collagenase $\mathrm{P}$ enzymatic activity. For the direct primary immune cell isolation method, 70 - and $40-\mu \mathrm{m}$ filtrations were performed to obtain single-cell suspensions and then cells were subsequently fixed in 1\% paraformaldehyde (Sigma; P6148) in Dulbecco's phosphate-buffered saline on ice for 10 minutes. For the density-dependent immune cell isolation method, filtered single-cell suspensions were carefully overlaid on $10 \mathrm{~mL}$ of either histopaque (Sigma; 10771) or lympholyte (Cedarlane, Burlington, NC; CL5031) and centrifuged at $400 \times g$ for 30 minutes with no brake. Following separate interface and pellet collection, a wash step in autoMACS Running Buffer was performed before fixation. For the comparison between cell isolation methods, six pairs of $m d x$ quadriceps ( $n=3 \mathrm{M}$ and $3 \mathrm{~F})$ were pooled and separated into three aliquots for equal distribution of cells between the three different isolation techniques. For blood leukocyte isolation, $50 \mu \mathrm{L}$ of blood obtained via submandibular blood collection was incubated with $2 \mathrm{~mL}$ of RBC Lysis Buffer (Thermo Fisher; 00433357) for 5 minutes and then fixed, as described earlier in this paragraph. Staining and analytical flow cytometry were completed within 24 to 96 hours of fixation for all experiments.

\section{Skeletal Muscle Single-Cell Suspension Staining and Flow Cytometry}

Following fixation of the single-cell suspensions, volumes of each sample were measured and adjusted to equal volumes with autoMACS Running Buffer. Flow cytometry antibodies used were as follows: CD45 (phycoerythrin-Cy7;

Table 1 Primer Sequences and Predicted Sizes for Quantitative PCR Experiments

\begin{tabular}{|c|c|c|c|}
\hline Gene & Protein product & Primer sequence & Amplicon, bp \\
\hline Actb & $\beta$-Actin (endogenous control) & $\begin{array}{l}\text { F: 5'-GATCAAGATCATTGCTCCTCCTG-3' } \\
\text { R: 5'-AGGGTGTAAAACGCAGCTCA-3' }\end{array}$ & 183 \\
\hline Ccl4 & Chemokine ( $\mathrm{C}-\mathrm{C}$ motif) ligand 4 & $\begin{array}{l}\text { F: 5'-AACCTAACCCCGAGCAACAC-3' } \\
\text { R: 5'-AGGGTCAGAGCCCATTGGTG-3' }\end{array}$ & 111 \\
\hline Ccr5 & CCR5 & $\begin{array}{l}\text { F: 5'-TGAGACATCCGTTCCCCCTA-3' } \\
\text { R: 5'-AATCCATCCTGCAAGAGCCAGA-3' }\end{array}$ & 50 \\
\hline $\operatorname{Tnf}$ & Tumor necrosis factor- $\alpha$ & $\begin{array}{l}\text { F: 5'-CCACGTCGTAGCAAACCACC-3' } \\
\text { R: 5'-TTGAGATCCATGCCGTTGGC-3' }\end{array}$ & 90 \\
\hline$I l 1 b$ & IL-1 $\beta$ & $\begin{array}{l}\text { F: 5'-TGCCACCTTTTGACAGTGATG-3' } \\
\text { R: 5'-TGATGTGCTGCTGCGAGATT-3' }\end{array}$ & 138 \\
\hline
\end{tabular}

$F$, forward; $R$, reverse. 
Thermo Fisher; 25045182), CD11b (allophycocyanin; Biolegend, San Diego, CA; 101212), F4/80 (fluorescein isothiocyanate; Biolegend; 123108), CD68 (BV605; Biolegend; 137021), CD206 [peridinin-chlorophyll-protein (PerCP)-eFluo710; Thermo Fisher; 46206182], LY6C (eFluo450; Thermo Fisher; 48593282), MHC II (BV650; Biolegend; 107639), LY6G (allophycocyanin/FIRE750; Biolegend; 127652), and CCR2 (phycoerythrin; R\&D; FAB5538P). An aliquot (100 $\mu \mathrm{L})$ of each sample was taken in round-bottom 5-mL flow tubes, and extracellular staining was performed for 45 minutes on ice. Excess antibody was washed using autoMACS Running Buffer, followed by intracellular staining using $40 \mu \mathrm{L}$ of $0.5 \%$ Tween-20 (Sigma; P1379) in Dulbecco's phosphate-buffered saline as the permeabilizer. UltraComp eBeads (Thermo Fisher; 01222242) were used as single-color controls for compensation. Samples were washed again with autoMACS Running Buffer, and as an internal control $2000(2 \mu \mathrm{L})$ AccuCount Blank Particles (Spherotech, Lake Forest, IL; ACBP10010) were added to each sample before flow cytometry to enable calculation of total cell counts in each sample. Immune cell populations were gated with the markers to distinguish the following populations: immune $\left(\mathrm{CD} 45^{+}\right)$, myeloid enriched $\left(\mathrm{CD} 45^{+} \mathrm{CD} 11 \mathrm{~b}^{+}\right)$, neutrophils $\left(\mathrm{CD} 45^{+} \mathrm{CD}_{11 \mathrm{~b}^{+}} \mathrm{LY} 6 \mathrm{G}^{+}\right)$, macrophages $\left(\mathrm{CD} 45^{+} \mathrm{CD} 11 \mathrm{~b}^{+}\right.$ $\mathrm{LY} \mathrm{G}^{-} \mathrm{F} 4 / 80^{\mathrm{Hi} / \mathrm{Lo}} \mathrm{CD}^{+} 8^{+}$), infiltrating monocytes $\left(\mathrm{CD} 45^{+}\right.$

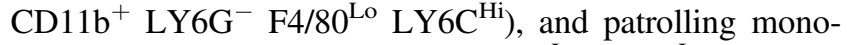

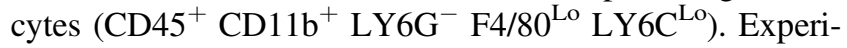
ments were conducted in the Analytical Cytometry Shared Resource at The Ohio State University using a Becton Dickinson LSRFortessa Flow Cytometrer (Becton Dickinson, Franklin Lakes, NJ), and all data were analyzed using FlowJo software Enzymatically-inactive Tissue-type Plasminogen Activator Reverses Disease Progression in the Dextran Sulfate Sodium Mouse Model of Inflammatory Bowel Disease version 10.7.1 (Becton Dickinson).

\section{Fluorescently Activated Cell Sorting, RNA Isolation, and Droplet Digital PCR}

Single-cell suspensions were prepared by the direct immune cell isolation method, as described above, from Het $(n=2 \mathrm{M}$ and $4 \mathrm{~F})$ and $m d x(n=3 \mathrm{M}$ and $3 \mathrm{~F})$ quadriceps. Freshly isolated unfixed cells were extracellularly stained with the following: CD45 (phycoerythrin-Cy7; Thermo Fisher; 25045182), CD11b (allophycocyanin; Biolegend; 101212), LY6G (allophycocyanin/FIRE750; Biolegend; 127652), F4/80 (PerCP/Cy5.5; Biolegend; 123128), CCR2 (fluorescein isothiocyanate; Biolegend; 150608), and LY6C (phycoerythrin; Thermo Fisher; 12593282), as described above. The cell populations isolated were as follows: infiltrating monocytes $\left(\mathrm{CD} 45^{+} \mathrm{CD} 11 \mathrm{~b}^{+} \mathrm{LY} 6 \mathrm{G}^{-} \mathrm{F} 4 / 80^{\mathrm{Lo}}\right.$ LY6C ${ }^{\mathrm{Hi}}$ ), patrolling monocytes and $\mathrm{LY} 6 \mathrm{C}^{-/ \mathrm{Lo}}$ myeloid cells $\left(\mathrm{CD}_{4}{ }^{+} \mathrm{CD}_{11 \mathrm{~b}^{+}} \mathrm{LY} \mathrm{G}^{-} \mathrm{F} 4 / 80^{\mathrm{Lo}} \mathrm{LY}^{-} \mathrm{C}^{-/ \mathrm{Lo}}\right), \mathrm{F} 4 / 80^{\mathrm{Hi}}$ $\mathrm{CCR}^{+}\left(\mathrm{CD} 45^{+} \mathrm{CD} 11 \mathrm{~b}^{+} \mathrm{LY} 6 \mathrm{G}^{-} \mathrm{F} 4 / 80^{\mathrm{Hi}} \mathrm{CCR} 2^{+}\right)$, and

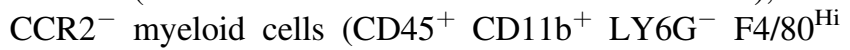

CCR2 ${ }^{-}$). UltraComp eBeads (Thermo Fisher; 01222242) were used as single-color controls for compensation in real time. The experiments were conducted in the Analytical Cytometry Shared Resource at The Ohio State University using the Becton Dickinson FACSAria III. Following fluorescently activated cell sorting, samples were pooled in duplicate and RNA was isolated from the cell populations using a NucleoSpin RNA XS kit (Takara, Mountain View, CA; 740902), according to the manufacturer's instructions. Purified RNA was reverse transcribed into cDNA, as described above. To absolutely quantify gene expression, digital droplet PCR was conducted using the synthesized cDNA. Droplet production and analysis were performed using the QX200 Droplet Digital PCR System (Bio-Rad). Targets were amplified and detected using commercially available primer/FAM-probe kits: Mrcl (Bio-Rad; 5095688), Spp1 (Bio-Rad; 5108866), Nos2 (Bio-Rad; 5121694), Colla (Bio-Rad; 5092596), and Timd4 (Bio-Rad; 5113448). Target copies per $20-\mu \mathrm{L}$ reaction were calculated in QuantaSoft Analysis Pro software version 1.7 (Bio-Rad) and normalized to the RNA (ng) input into the reverse transcription reaction.

\section{Statistical Analysis}

All data are displayed as means \pm SEM. For comparison of two groups, the two-tailed, unpaired $t$-test was utilized. Statistical comparisons between more than two groups were analyzed using one-way analysis of variance with either Tukey or Benjamini/Krieger/Yekutieli multiple-comparison post-hoc tests. Group variances were first compared using the BrownForsythe test. Tests were performed in GraphPad Prism software version 9.0.0 (GraphPad Prism Software, San Diego, CA). $P \leq 0.05$ was considered significantly different.

\section{Results}

Het Quadriceps Muscles Contain Higher Cytokine Levels than Mdx Quadriceps Muscles during the Early Inflammatory Phase

To evaluate differences in cytokine levels between wildtype C57BL/10 controls (C57), $m d x$, and Het skeletal muscles during the early inflammatory phase observed in muscular dystrophy, an unbiased mouse-specific cytokine array enabling the simultaneous detection of up to $40 \mathrm{cy}-$ tokines was performed on pooled quadriceps lysates of each genotype (Figure 1A). After performing pixel densitometry, 21 cytokines were found to be up-regulated in both dystrophic genotypes relative to $\mathrm{C} 57$, with chemokine (C-C motif) ligand (CCL) 2, IL-1ra, and CCL12 representing the three highest fold changes in $m d x$ compared with wild-type, with 33.65-fold, 22.53-fold, and 11.22-fold higher levels, respectively (Figure 1B). When comparing $m d x$ with the more severe Het mouse model, increased levels of many chemokines, cytokines primarily responsible for mediating 
A
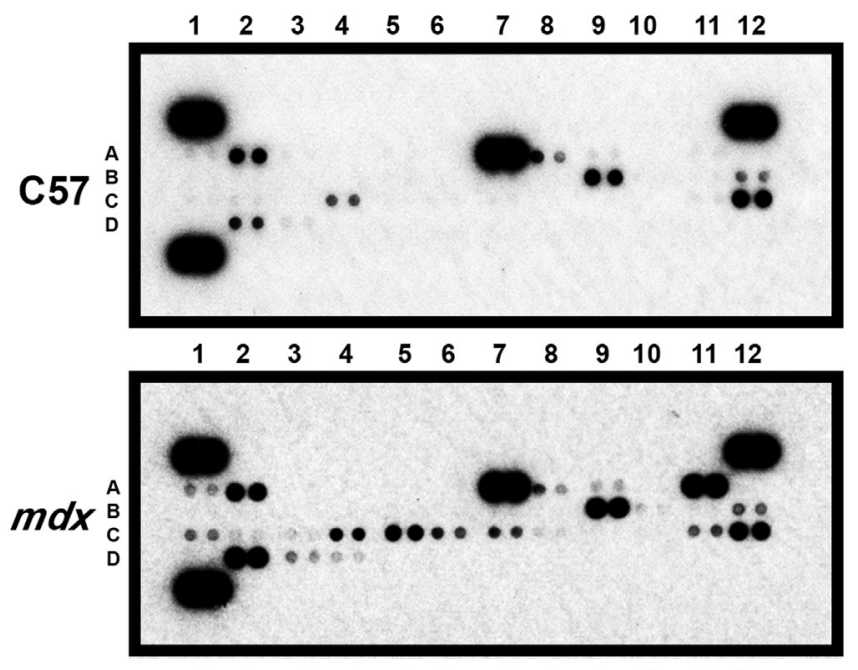

$\begin{array}{llllllllllll}1 & 2 & 3 & 4 & 5 & 6 & 7 & 8 & 9 & 10 & 11 & 12\end{array}$

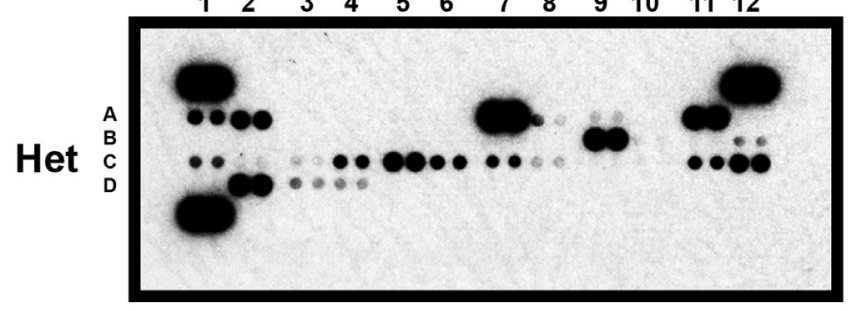

B

\begin{tabular}{|c|c|c|c|c|}
\hline L\# & Cytokine & $\boldsymbol{m d x} \mathbf{l C 5 7}$ & Het/C57 & Het/mdx \\
\hline A1 & CXCL13 & 1.4 & 3.85 & 2.75 \\
\hline A2 & C5/C5a & 1.2 & 1.26 & 1.05 \\
\hline A7 & sICAM-1 & 1 & 1 & 1 \\
\hline A9 & IL-1a & 1.98 & 1.66 & 0.84 \\
\hline A11 & IL-1ra & 22.53 & 22.53 & 1 \\
\hline A12 & IL-2 & 0.83 & 1.55 & 1.86 \\
\hline B2 & IL-4 & 0.56 & 0.57 & 1.02 \\
\hline B6 & IL-10 & 1.1 & 0.59 & 0.54 \\
\hline B7 & IL-13 & 0.52 & 0.64 & 1.22 \\
\hline B8 & IL-12 p70 & 0.42 & 0.13 & 0.32 \\
\hline B9 & IL-16 & 1.34 & 1.36 & 1.02 \\
\hline B10 & IL-17 & 2.36 & 1.32 & 0.56 \\
\hline B11 & IL-23 & 2.63 & 3.05 & 1.16 \\
\hline B12 & IL-27 & 0.98 & 0.61 & 0.63 \\
\hline C1 & CXCL10 & 3.15 & 4.48 & 1.42 \\
\hline C3 & CXCL1 & 2.18 & 2.38 & 1.09 \\
\hline C4 & M-CSF & 1.65 & 1.94 & 1.17 \\
\hline C5 & CCL2 & 33.65 & 42.92 & 1.28 \\
\hline C6 & CCL12 & 11.22 & 20.95 & 1.87 \\
\hline C7 & CXCL9 & 6.03 & 8.63 & 1.43 \\
\hline C8 & CCL3 & 6.42 & 10.98 & 1.71 \\
\hline C9 & CCL4 & 1.96 & 4.99 & 2.54 \\
\hline C10 & CCL5 & 8.77 & 17.85 & 2.04 \\
\hline D2 & TIMP-1 & 2.25 & 2.26 & 1 \\
\hline D3 & TNF- $\alpha$ & 2.5 & 2.6 & 1.04 \\
\hline D4 & TREM-1 & 4.86 & 9.06 & 1.87 \\
\hline & & & & \\
\hline
\end{tabular}

C
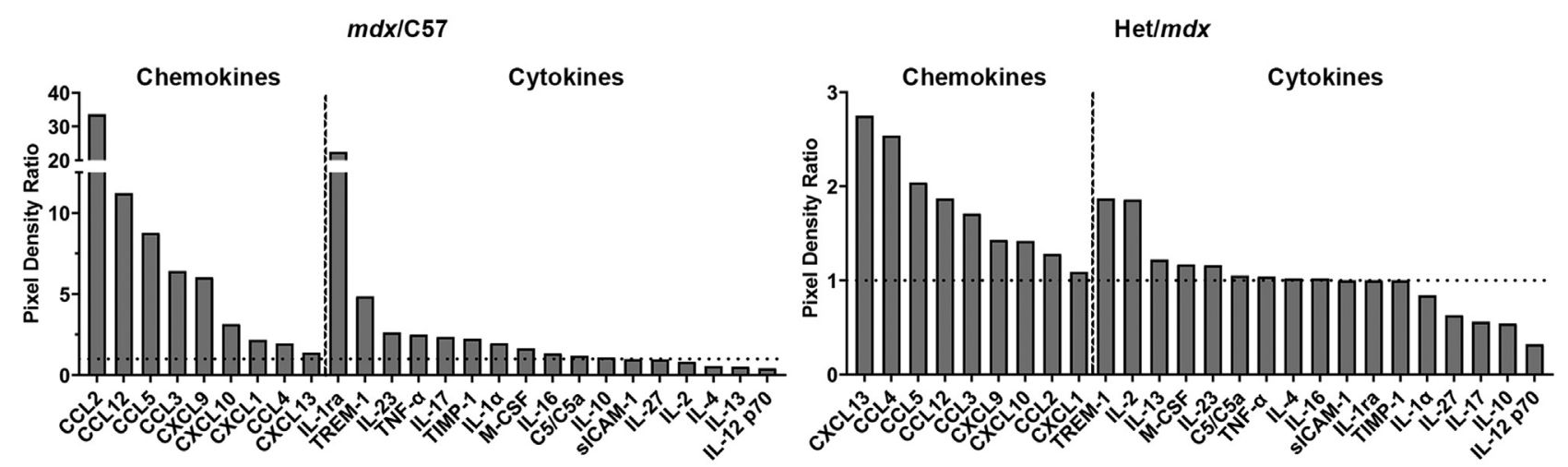

Figure 1 Unbiased analysis of cytokine protein levels from muscles of dystrophic mouse models. A: Proteome profiler dot blots incubated with pooled 4week-old C57 wild-type, $m d x$, and Het quadriceps lysates. Technical duplicate dots correspond to the protein levels of a single cytokine, which are labeled with a coordinate [letter, number (L\#)]. B: Cytokine pixel density ratios of $m d x / C 57$, Het/C57, and Het/mdx measured from technical duplicate blots from pooled samples. Cytokines can be identified on the blot in $\mathbf{A}$ using the coordinates listed under L\#. C: Mdx/C57 and Het/mdx chemokine and cytokine pixel density ratios displayed as a bar graph with a dotted horizontal line at $y=1.0$. Chemokines and cytokines detected in the array are separated by a dashed vertical line. $\mathrm{CCL}$, chemokine (C-C motif) ligand; M-CSF, macrophage colony stimulating factor; sICAM, soluble intercellular adhesion molecule; TIMP, tissue inhibitor of metalloproteinases; TNF- $\alpha$, tumor necrosis factor- $\alpha$; TREM, triggering receptor expressed on myeloid cells.

immune cell chemotaxis toward injury, including the following: CXCL13, CXCL10, CXCL1, CCL2, CCL12, CXCL9, CCL3, CCL4, and CCL5 (Figure 1, B and C) were observed. In addition to chemokines, IL-2 and triggering receptor expressed on myeloid cells 1 (TREM-1) were elevated, which are indicative of lymphoid and myeloid inflammation, respectively. ${ }^{35,36}$ Levels of anti-inflammatory IL-10 were correspondingly lower in Het relative to $m d x$ quadriceps, further suggesting enhanced inflammation in Het mice when compared with $m d x$ mice (Figure 1C). 

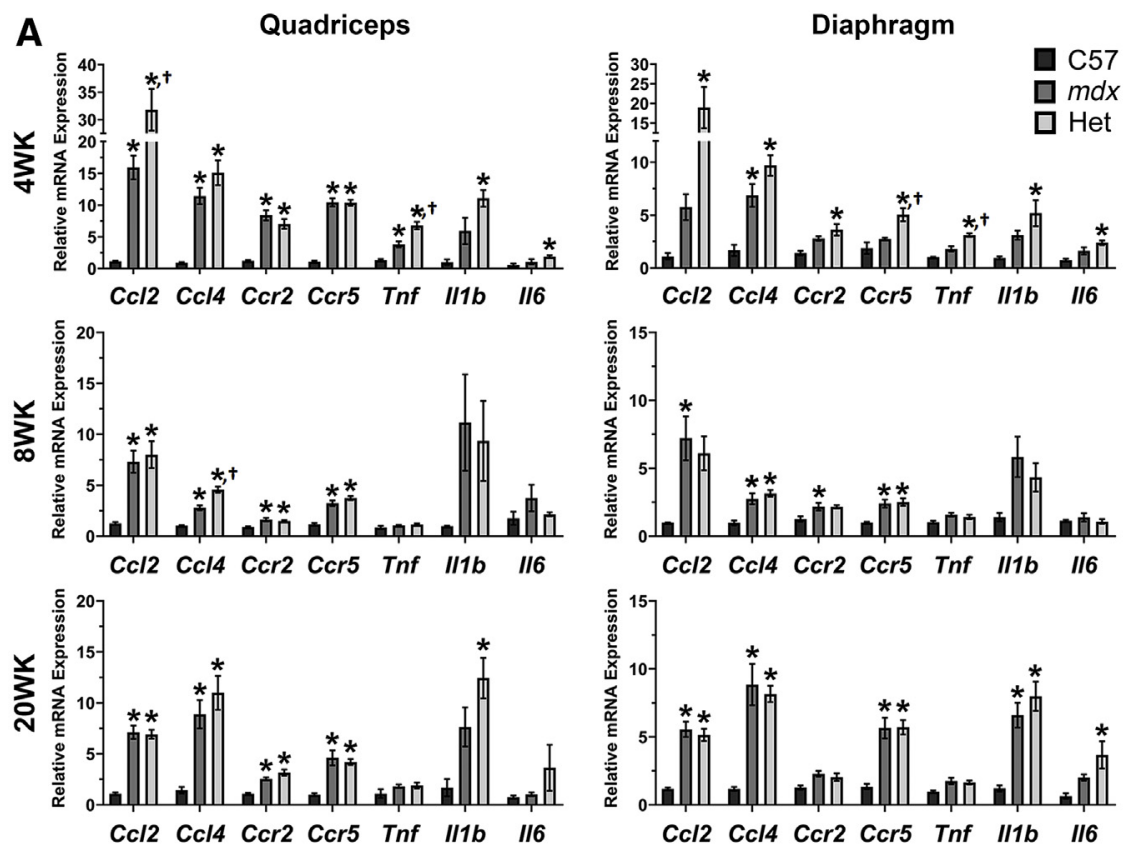

B

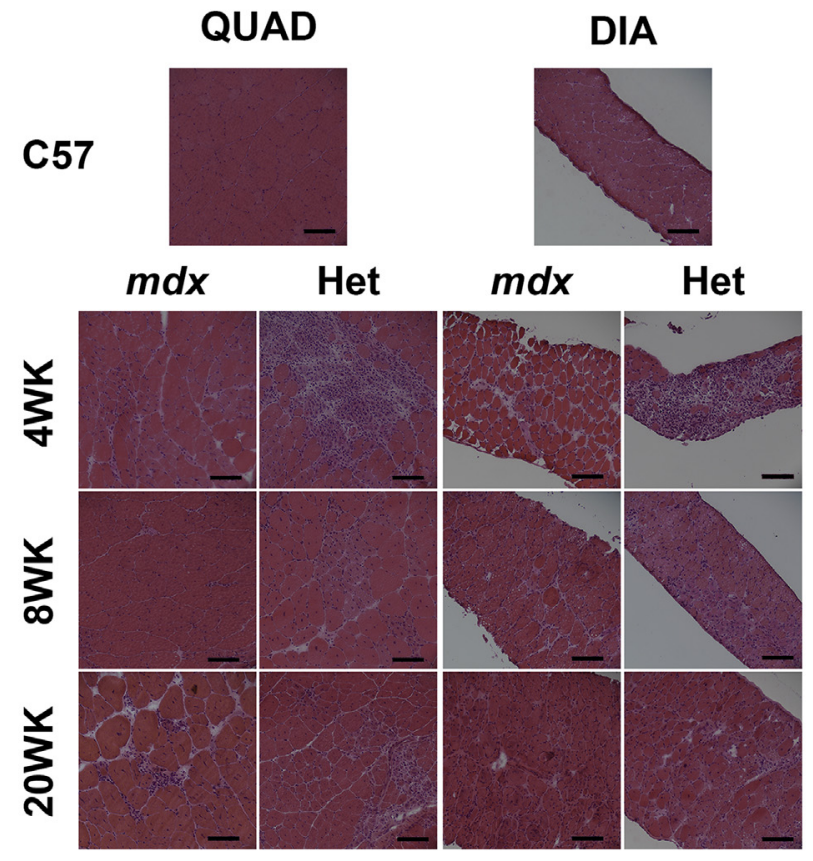

Figure 2 Temporal gene expression and histology comparing dystrophic mouse models A: Gene expression analysis of cytokines and chemokine receptors in C57, $m d x$, and Het quadriceps (QUADs) and diaphragms (DIAs) at 4, 8, and 20 week of age. Transcripts quantified by quantitative PCR from left to right are as follows: Ccl2, Ccl4, Ccr2, Ccr5, Tnf, Il1b, and Il6. Relative quantification was performed using $\beta$-actin (Actb) as an endogenous control. Statistical analysis was performed with one-way analysis of variance and the Tukey multiple-comparison post-hoc test. B: Hematoxylin and eosin staining of $m d x$ and Het quadriceps and diaphragms at 4, 8, and 20 weeks of age, compared with $\mathrm{C} 57$ at 20 weeks of age. ${ }^{*} P \leq 0.05$ versus $C 57 ;{ }^{\dagger} P \leq 0.05$ versus $m d x$. Scale bars $=100 \mu \mathrm{m}(\mathbf{B})$.

Gene Expression for Cytokine and Chemokine Signaling Is Increased during the Early Inflammatory Phase and Diminishes in Both Dystrophic Models during Disease Progression

After performing an unbiased cytokine assessment, gene expression for $C c l 2, C c l 4, C c r 2, C c r 5, T n f, I l 1 \beta$, and $I l 6$ was measured in C57, $m d x$, and Het quadriceps and diaphragms at 4,8 , and 20 weeks of age to evaluate temporal inflammation between the two dystrophic phenotypes (Figure 2). In 4-week-old mouse quadriceps, $C c l 2, C c l 4$, $C c r 2, C c r 5$, and $T n f$ gene expression was significantly upregulated in both dystrophic models compared with C57 (one-way analysis of variance; Tukey; $P \leq 0.05$ ) (Figure 2A). Illb (11.05 \pm 1.32 versus $1.00 \pm 0.44$; $P=0.007)$ and $I l 6(1.89 \pm 0.21$ versus $0.53 \pm 0.24$; $P=0.047)$ expression levels were only significantly upregulated in Het quadriceps compared with C57 (Figure 2A). Ccl2 (31.80 \pm 3.80 versus $15.92 \pm 1.87$; $P=0.004)$ and $\operatorname{Tnf}(6.77 \pm 0.59$ versus $3.81 \pm 0.47$; $P=0.003)$ gene expression levels were significantly upregulated in Het compared with $m d x$ quadriceps (Figure 2A). In the 4-week-old mouse diaphragms, Ccl4 gene expression was significantly up-regulated in both dystrophic models compared with C57 $(P \leq 0.05)$ (Figure 2A). Only $C c l 2(18.92 \pm 5.25$ versus $1.11 \pm 0.31$; 
$P=0.023), C c r 2(3.61 \pm 0.17$ versus $1.41 \pm 0.21$;

$P=0.011), \quad C c r 5(5.03 \pm 0.62$ versus $1.88 \pm 0.83$;

$P=0.003), \operatorname{Tnf}(3.11 \pm 0.17$ versus $1.04 \pm 0.02$;

$P<0.001), \quad I l l b$ (5.17 \pm 1.24 versus $0.94 \pm 0.15$;

$P=0.026)$, and $I l 6$ (2.39 \pm 0.22 versus $0.74 \pm 0.13$;

$P=0.008)$ expression levels were significantly upregulated in Het diaphragms compared with C57 (Figure 2A). Ccr5 (5.03 \pm 0.62 versus $2.76 \pm 0.11$; $P=0.011)$ and $\operatorname{Tnf}(3.11 \pm 0.17$ versus $1.80 \pm 0.25$; $P=0.001)$ were up-regulated in Het diaphragms compared with $m d x$ (Figure 2A). The largest inflammatory gene expression differences between C57 and dystrophic muscle were at 4 weeks, which supports the peak of inflammation at this time point identified in previous studies (Figure 2A). ${ }^{6,37}$

Similar patterns of significantly increased inflammatory gene expression in dystrophic compared with C57 muscles continue at 8-week-old and 20-week-old time points, although the magnitude of differences is lower at the later time points (Figure 2A). The only remaining significant increase in Het compared with $m d x$ skeletal muscles at the later ages was $\mathrm{Ccl} 4$ quadriceps expression at 8 weeks $(4.57 \pm 0.29$ versus $2.80 \pm 0.24$; $P=0.0032)$. Ccl4 is also more up-regulated in both dystrophic tissues at 20 weeks, which may indicate more lymphoid infiltration during the fibrotic phase of pathology (Figure 2A). These temporal changes in gene expression and differences between dystrophic models correlate with the more severe pathology observed in Het compared with $m d x$ skeletal muscles (Figure 2B). Fibrosis becomes apparent by 20 weeks of age for both genotypes, with higher amounts visible in Het muscles, as previously quantified. $^{7}$

\section{Direct Primary Immune Cell Isolation Substantially} Improves Yield of Dystrophic Skeletal Muscle Immune Cells Compared with Density-Dependent Centrifugation Methods

Because we observed significant differences in several chemokines and cytokines that mediate immune cell influx into the tissues, we next measured immune cell infiltration into the single muscle tissues of $m d x$ and Het mice and compared them with C57 mice. Several published studies use density-mediated cell separation techniques (lympholyte/histopaque) to remove tissue debris and enrich mononuclear cells. ${ }^{21,38,39}$ However, studies of immune cell isolation from other tissues support that, although densitymediated mononuclear cell isolation works well for peripheral blood mononuclear cells, altered cell size and granularity of tissue-infiltrated immune cells result in significant loss of leukocyte yield. ${ }^{40}$ These methods can potentially result in underrepresentation of specific immune cell populations isolated from skeletal muscle tissues. To achieve the goals of maximizing cell yield and minimizing cell manipulation, we compared previously used muscle isolation techniques with a direct immune cell isolation method recently described for heart. ${ }^{41,42}$

Immune cell numbers from $m d x$ quadriceps muscles with and without density-mediated mononuclear cell isolation were compared using either histopaque or lympholyte on the same pooled samples. Myeloid cell populations (Supplemental Figure S1B) were found in the pellets generated from lympholyte and histopaque isolation (Figure 3, A and B). Analysis of the pellets indicated 38.6\% and $71.3 \%$ of $\mathrm{CD}^{4} 5^{+}$leukocytes were lost by isolating cells at the gradient interface of histopaque and lympholyte, respectively, compared with the direct isolation method confirmed via $\mathrm{CD}^{+} 5^{+}$back gating (Supplemental Figure S1A and Figure 3C). Further analysis of different immune cell populations showed $24 \%$ to $38 \%$ loss of neutrophils and monocytes (infiltrating and patrolling) in histopaque pellets and $60 \%$ to $70 \%$ loss in lympholyte pellets. More importantly, $80 \%$ to $90 \%$ of $\mathrm{F} 4 / 80^{\mathrm{Hi}} \mathrm{CD}^{+} 8^{+}$macrophages were found in both pellets, suggesting significant underrepresentation of this potent immune cell population by density-mediated immune cell isolation from tissue digests. Substantially more cells were lost using lympholyte than when using histopaque (Figure 3C).

To define the mechanism underlying the loss of yield observed with density-mediated cell separation techniques, we show that leukocytes exhibit different sizes [forward scatter area (FSC-A)] and granularities [side scatter area (SSC-A)], depending on isolation from blood versus quadriceps muscles of Het mice. Leukocytes isolated from the blood were smaller, including the following: total immune cells $(69,293.5 \pm 660.0$ versus $81,864.7 \pm 979.0 \mathrm{FSC}-\mathrm{A}$; $t$ test; $P<0.001$ ) (Supplemental Figure S2A), myeloid cells $(78,863.7 \pm 767.0$ versus $83,415.7 \pm 1015.3$ FSC-A; $P=0.005$ ) (Supplemental Figure S2B), neutrophils $(79,228.3 \pm 931.3$ versus $94,347.5 \pm 1250.3$ FSC-A; $P<0.001$ ) (Supplemental Figure S2C), and monocytes $(76,541.2 \pm 1337.24$ versus 92,455.3 \pm 317.5 FSC-A; $P<0.001$ ) (Supplemental Figure S2D). Blood immune cells were also less granulated: immune cells $(6258.7 \pm 278.7$ versus $18,619.3 \pm 785.4$ SSC-A; $P<0.001)$, myeloid cells $(10,642.5 \pm 189.5$ versus $19,139.5 \pm 828.2$ SSC-A $\quad P<0.001)$, neutrophils $(12,023.8 \pm 135.1$ versus $15,637.7 \pm 597.1$ SSC-A; $P<0.001)$, and monocytes $(6818.7 \pm 234.3$ versus $21,185.2 \pm 951.7$ SSC-A; $P<0.001)$. These results collectively showed that immune cells infiltrated into the muscles are larger and more granular compared with their counterparts in the circulation. Thus, lympholyte/ histopaque-mediated cell enrichment is not as efficient of a technique to measure tissue-infiltrated immune cell populations and results in the biased enrichment of smaller and less granular cells at the interphase. The direct isolation method has the additional advantage of not exposing immune cells to the polysaccharide solution of density centrifugation methods. Therefore, all subsequent experiments use the direct isolation method. 


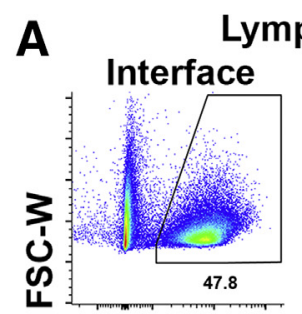

CD45

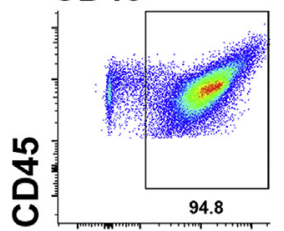

CD11b

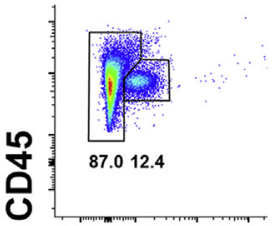

LY6G

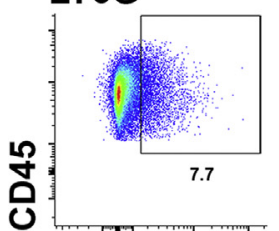

CD68

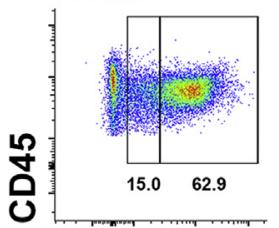

LY6C

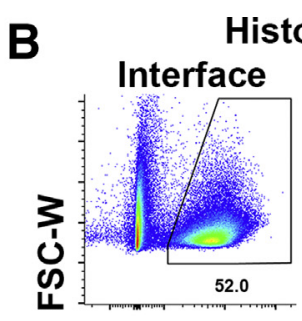

CD45
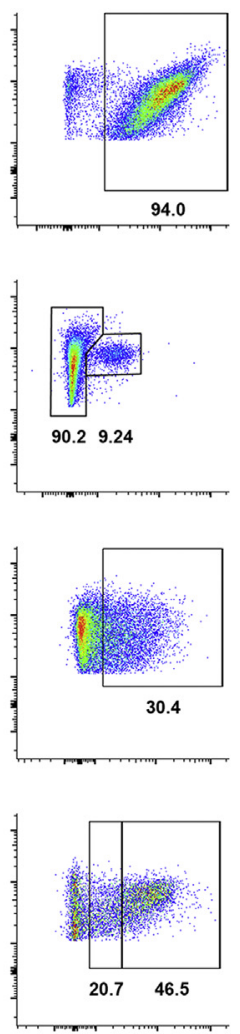

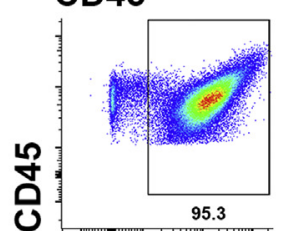

CD11b
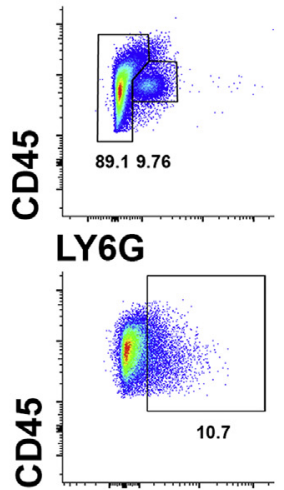

\section{CD68}

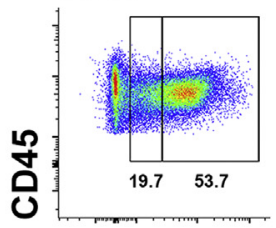

LY6C

$\mathrm{C}$

\begin{tabular}{|c|c|}
\hline Gating & Population \\
\hline CD45 ${ }^{+}$ & Leukocytes \\
\hline $\mathrm{CD}_{4} 5^{+} \mathrm{CD} 11 \mathrm{~b}^{+}$ & Myeloid \\
\hline $\mathrm{CD} 45^{+} \mathrm{CD} 11 \mathrm{~b}^{+} \mathrm{LY}_{6 \mathrm{G}^{+}}$ & Neutrophil \\
\hline $\mathrm{CD}^{2} 5^{+} \mathrm{CD} 11 \mathrm{~b}^{+} \mathrm{LY} 6 \mathrm{G}^{-} \mathrm{F} 4 / 80^{\mathrm{Hi}} \mathrm{CD} 8^{+}$ & Macrophage \\
\hline $\mathrm{CD} 45^{+} \mathrm{CD} 11 \mathrm{~b}^{+} \mathrm{LY} 6 \mathrm{G}^{-} \mathrm{F} 4 / 80^{\mathrm{LO}} \mathrm{LY} \mathrm{CC}^{\mathrm{Hi}}$ & Inf. Monocyte \\
\hline $\mathrm{CD}^{4} 5^{+} \mathrm{CD} 11 \mathrm{~b}^{+} \mathrm{LY} 6 \mathrm{G}^{-} \mathrm{F} 4 / 80^{\mathrm{LO}} \mathrm{LY} \mathrm{C}^{\mathrm{Lo}}$ & Pat. Monocyte \\
\hline
\end{tabular}

\begin{tabular}{|c|c|c|}
\hline Population & Histo. Pellet \% & Lympho. Pellet \% \\
\hline Leukocytes & $38.56 \%$ & $71.33 \%$ \\
\hline Myeloid & $37.59 \%$ & $71.15 \%$ \\
\hline Neutrophil & $38.10 \%$ & $63.63 \%$ \\
\hline Macrophage & $84.06 \%$ & $90.95 \%$ \\
\hline Inf. Monocyte & $24.27 \%$ & $59.44 \%$ \\
\hline Pat. Monocyte & $33.57 \%$ & $73.66 \%$ \\
\hline
\end{tabular}

Figure 3 Comparison of flow cytometry analysis after direct versus density centrifugation methods of immune cell isolation from $m d x$ quadriceps muscles. $\mathbf{A}$ and $\mathbf{B}$ : Representative flow cytometry scatterplots and gating of immune cell populations collected from the interface and the pellets after lympholyte (A) and histopaque (B) density-dependent centrifugation of single-cell suspensions obtained by digesting $m d x$ muscles. C: Cell surface markers used for identifying total leukocytes and other innate immune cells of myeloid origin, including neutrophils, macrophages, and infiltrating (Inf.) and patrolling (Pat.) monocytes (left panel), and their relative frequencies in the histopaque and lympholyte pellets (right panel). FSC-W, forward scatter width; Histo., histopaque; Lympho., lympholyte.

\section{Mdx Quadriceps Muscles Contain a Greater Density of Myeloid Cells than Mdx Diaphragms}

To characterize different immune cell populations in C57 skeletal muscles and quantify differences in inflammation between $m d x$ and C57 skeletal muscles, immune cell isolations using the direct method were performed separately using quadriceps and diaphragm muscles, from sex-matched mice of both genotypes. The representative gating strategy is shown in Supplemental Figure S1B, with representative 
A
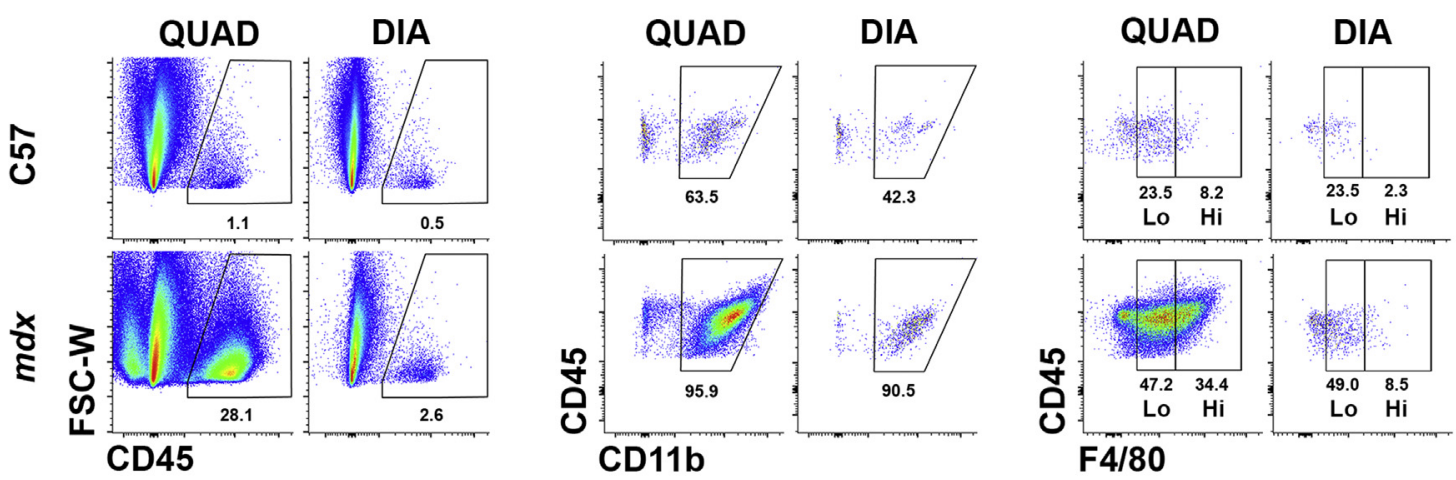

F4/80

B

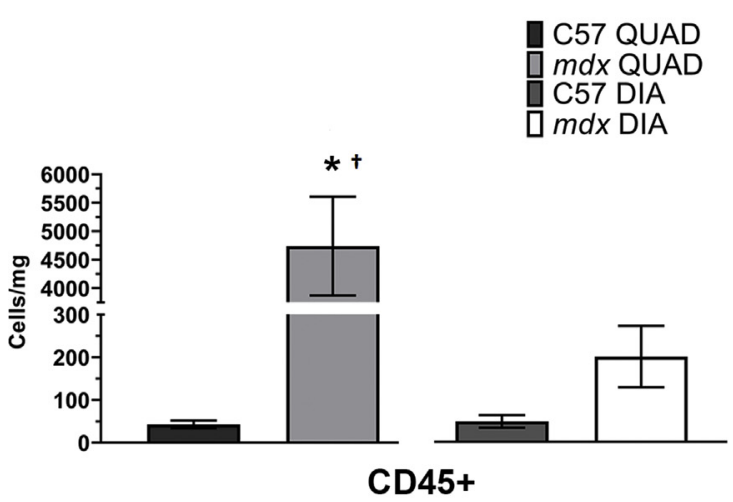

C

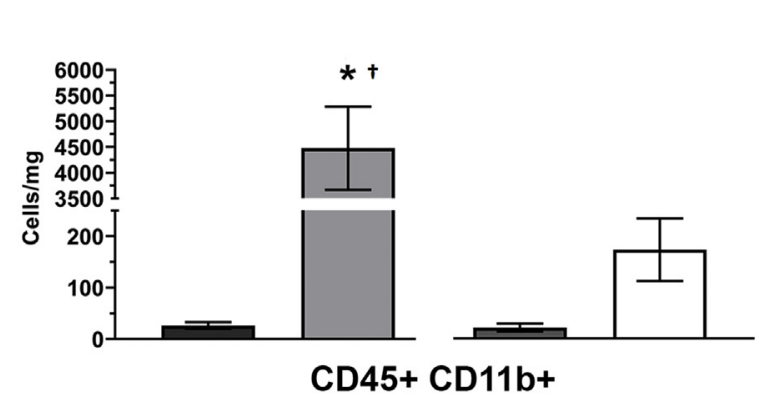

D

\section{$\mathbf{E}$}
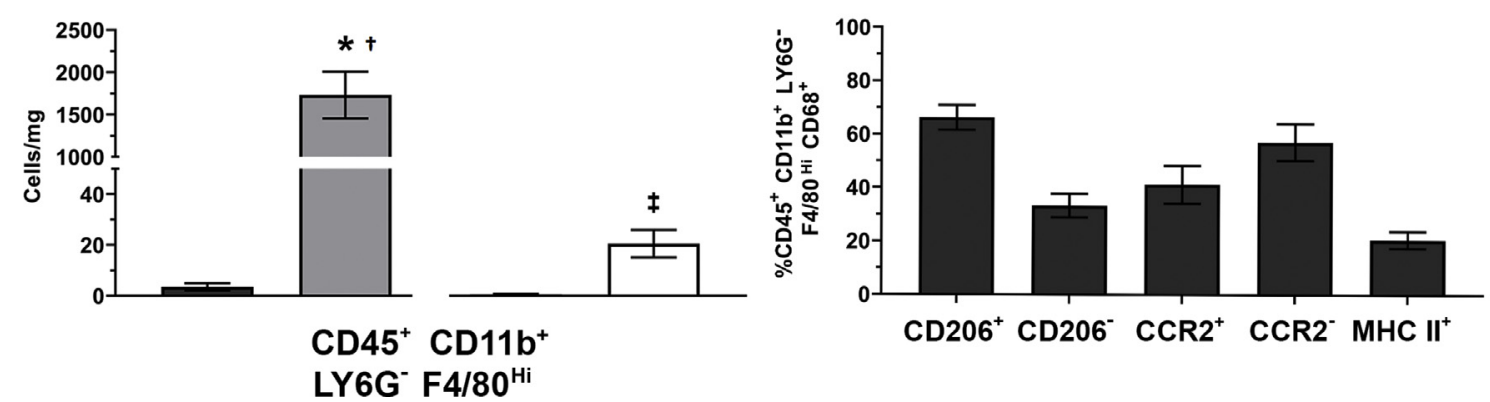

Figure 4 Comparison of immune cells in $\mathrm{C} 57$ and $m d x$ quadriceps (QUADs) and diaphragm (DIA) muscles analyzed by flow cytometry using direct isolation method. A: Representative flow cytometry dot plots for $\mathrm{CD} 45^{+}$leukocytes, CD45 ${ }^{+} \mathrm{CD} 11 \mathrm{~b}^{+}$myeloid cells, CD45 ${ }^{+} \mathrm{CD} 11 \mathrm{~b}^{+} \mathrm{LY}_{6 \mathrm{G}}{ }^{-} \mathrm{F} 4 / 80^{\mathrm{LO}}$ monocytes, and $\mathrm{CD} 45^{+} \mathrm{CD} 11 \mathrm{~b}^{+} \mathrm{LY}_{6 \mathrm{G}}{ }^{-} \mathrm{F} 4 / 80^{\mathrm{Hi}}$ macrophages in $\mathrm{C} 57$ and $m d x$ QUAD and DIA skeletal muscles. B: Absolute quantification of the number of CD45 ${ }^{+}$leukocytes. C:

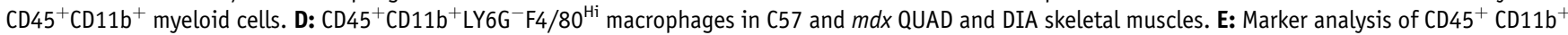
$\mathrm{LY} 6 \mathrm{G}^{-} \mathrm{F} 4 / 80^{\mathrm{Hi}} \mathrm{CD} 8^{+}$macrophages in $\mathrm{C} 57$ quadriceps. Statistical analysis was performed with $t$-test. ${ }^{*} P \leq 0.05$ versus $\mathrm{C} 57$ QUAD; ${ }^{\dagger} P \leq 0.05$ versus $m d x$ DIA; ${ }^{\ddagger} P \leq 0.05$ versus C57 DIA. FSC, forward scatter; MHC, major histocompatibility complex.

gating dot plots for each tissue and genotype in Figure 4A. Flow cytometry isotype controls for markers lacking distinct populations are displayed in Supplemental Figure S1C. Quadriceps and diaphragms of C57 mice exhibited similar levels of $\mathrm{CD}^{+} 5^{+}$leukocytes $(42.5 \pm 9.1$ versus $47.6 \pm 14.7$ cells/mg) at 4 weeks of age (Figure 4B). However, leukocyte numbers (per milligram of muscle tissue) were 100-fold and 10-fold higher in $m d x$ quadriceps and diaphragms, respectively. Immune cell density differences between C57 and $m d x$ skeletal muscle were assessed to demonstrate the severity of inflammation in dystrophic skeletal muscle. $M d x$ quadriceps contained significantly higher numbers of CD45 ${ }^{+}$immune $(4740.4 \pm 868.3$ versus $42.5 \pm 9.1$ cells/ $\mathrm{mg}$; $t$-test; $P=0.0002$ ) (Figure $4 \mathrm{~B}), \mathrm{CD} 11 \mathrm{~b}^{+}$myeloid cells $(4476.6 \pm 808.1$ versus $26.4 \pm 6.6$ cells $/ \mathrm{mg} ; P=0.0002)$ (Figure $4 \mathrm{C}$ ), and $\mathrm{F} 4 / 80^{\mathrm{Hi}}$ macrophages $(1730.6 \pm 275.7$ 
A

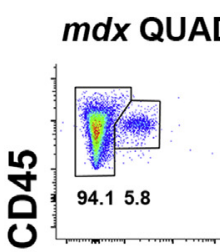

LY6G

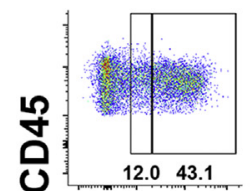

LY6C
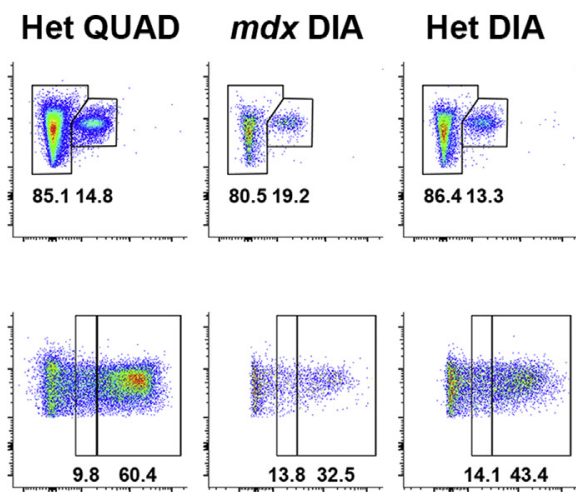

$9.8 \quad 60.4$

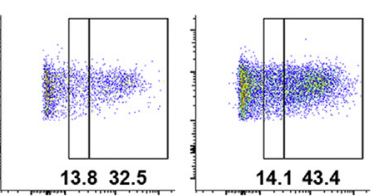

13.832 .5 14.143 .4

B

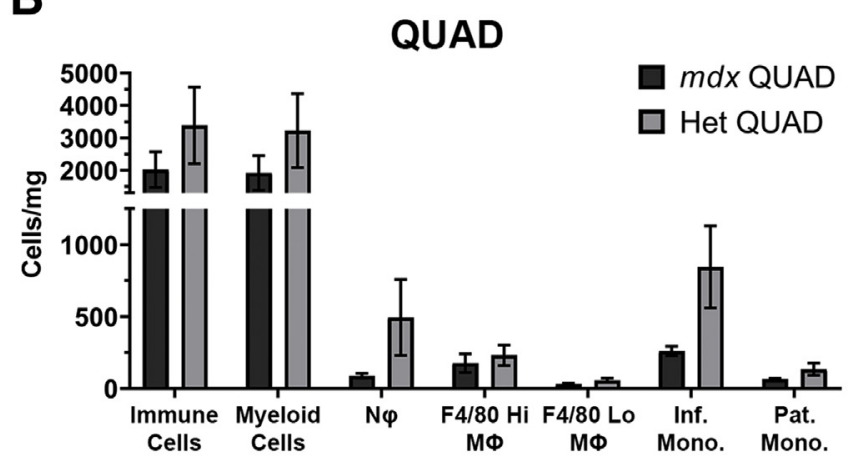

C
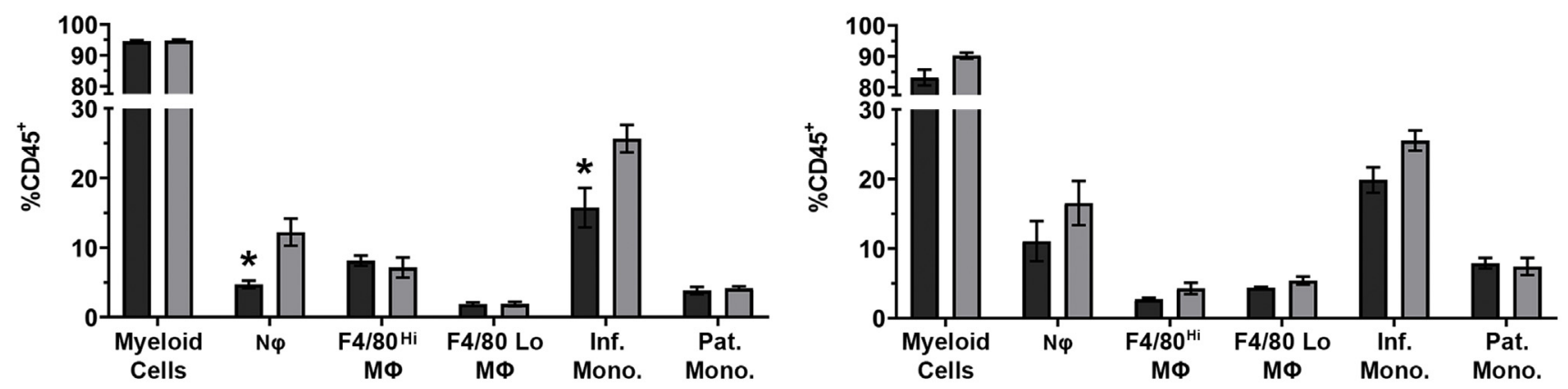

D
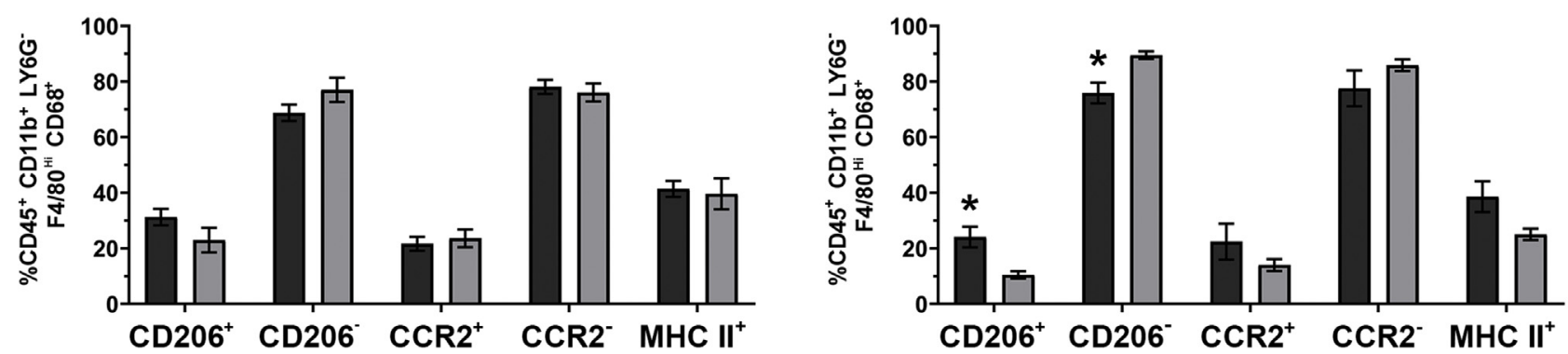

Figure 5 Flow cytometry analysis comparing myeloid populations in $m d x$ and Het quadriceps (QUADs) and diaphragm (DIA) muscles. A: Representative flow cytometry dot plots for neutrophils, monocytes, $\mathrm{F} 4 / 80^{\mathrm{Hi}}$ macrophages, and $\mathrm{CD} 206^{+} \mathrm{F} 4 / 80^{\mathrm{Hi}}$ macrophages in the QUAD and DIA of $m d x$ and Het mice. B: Bar graphs showing total cell counts of $\mathrm{CD} 5^{+}$leukocytes, $\mathrm{CD} 11 \mathrm{~b}^{+}$myeloid cells, $\mathrm{LY}_{6 \mathrm{G}}{ }^{+}$neutrophils $(\mathrm{N} \varphi), \mathrm{F} 4 / 80^{\mathrm{Hi}}$ macrophages $(\mathrm{M} \Phi)$, and $\mathrm{F} 4 / 80^{\mathrm{LO}}$ macrophages in the $m d x$ and Het skeletal muscles. C: Cell populations quantified as a percentage of the total immune cell population $\left(\%\right.$ CD45 $5^{+}$. D: Distribution of CD206, CCR2, and major histocompatibility complex (MHC) II in F4/80 ${ }^{\mathrm{Hi}}$ macrophages. Quantification for QUAD (left panel) and DIA (right panel) is shown. Statistical analysis was performed with $t$-test. ${ }^{*} P \leq 0.05$ versus Het. Inf. Mono., infiltrating monocytes; Pat. Mono., patrolling monocytes. 


\section{A}

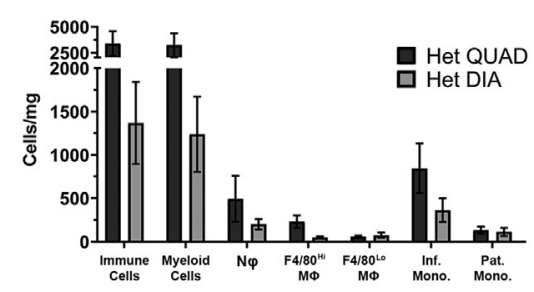

C

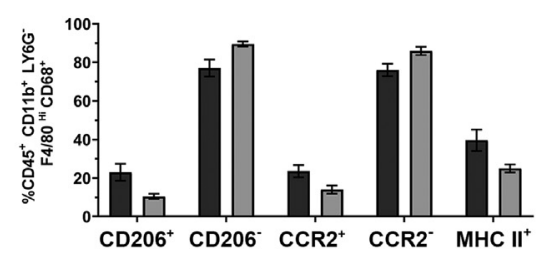

E

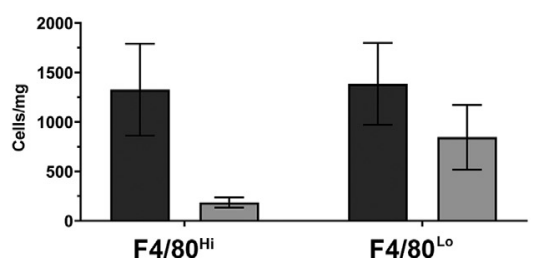

B

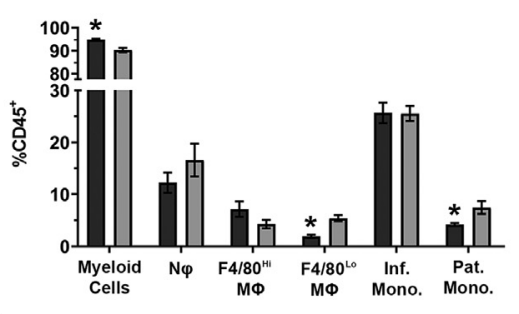

D

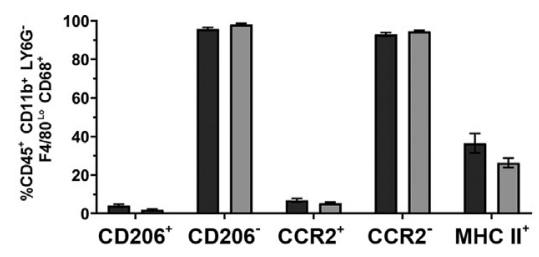

$\mathbf{F}$

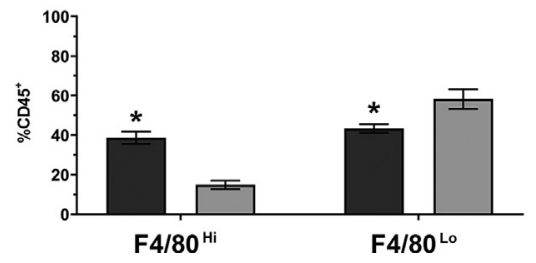

Figure 6 Flow cytometry analysis comparing myeloid populations in Het quadriceps (QUADs) and diaphragm (DIA) muscles. Absolute cell density (A) and frequency $\left(\% \mathrm{CD}_{4} 5^{+}\right)(\mathbf{B})$ of different immune cells in the QUAD and DIA of Het mice. Distribution of CD206, CCR2, and major histocompatibility complex (MHC) II in $\mathrm{F} 4 / 80^{\mathrm{Hi}}$ (C) and $\mathrm{F} 4 / 80^{\mathrm{LO}}$ (D) macrophages (MS). $\mathrm{F} 4 / 80^{\mathrm{Hi}}$ and $\mathrm{F} 4 /$ $80^{\mathrm{Lo}}$ and cell density (E) and $\% \mathrm{CD} 45^{+}$quantification $(\mathbf{F})$ in Het skeletal muscle. Statistical analysis was performed with $t$-test. ${ }^{*} P \leq 0.05$ versus Het DIA. Inf. Mono., infiltrating monocytes; $\mathrm{N} \varphi$, neutrophils; Pat. Mono., patrolling monocytes. versus $3.5 \pm 1.4$ cells/mg; $P=0.00009$ ) (Figure 4D) than C57 quadriceps. In addition, $m d x$ diaphragms contained significantly fewer cells of $\mathrm{CD}_{4} 5^{+}, \mathrm{CD} 11 \mathrm{~b}^{+}$, and $\mathrm{F} 4 / 80^{\mathrm{Hi}}$ populations than $m d x$ quadriceps $[199.5 \pm 71.8$ cells $/ \mathrm{mg}$ $(P=0.009), 172.7 \pm 61.9$ cells $/ \mathrm{mg}(P=0.008)$, and $20.5 \pm 5.4$ cells $/ \mathrm{mg}(P=0.003)$, respectively] (Figure 4 , B-D). $M d x$ diaphragms also contained significantly higher $\mathrm{F} 4 / 80^{\mathrm{Hi}}$ macrophage density than C57 diaphragms $(20.5 \pm 5.4$ versus $0.6 \pm 0.1$ cells $/ \mathrm{mg} ; P=0.021)$ (Figure 4D). In a parallel experiment, 8-week-old $m d x$ skeletal muscle contained more immune cells than C57 skeletal muscle; however, the differences in immune cell density were substantially lower than at 4 weeks of age (data not shown). Combined with the gene expression analysis, inflammation appears to diminish by 8 weeks of age in $m d x$ skeletal muscle.

In $\mathrm{C} 57$ muscles, $\mathrm{CD}_{1} 1 \mathrm{~b}^{+}$myeloid cells represented $60.2 \%$ of quadriceps and $42.4 \%$ of diaphragm $\mathrm{CD}^{4} 5^{+}$cells. Further analysis showed that most $(\geq 98 \%)$ of $\mathrm{CD} 11 \mathrm{~b}^{+}$cells were $\mathrm{F} 4 / 80^{\mathrm{Hi}}$ macrophages and $\mathrm{F} 4 / 80^{\mathrm{Lo}} \mathrm{LY} 6 \mathrm{C}^{+}$monocytes. However, C57 diaphragms trend lower than quadriceps in $\mathrm{F} 4 / 80^{\mathrm{Hi}}$ macrophage density $(0.6 \pm 0.1$ versus $3.5 \pm 1.4$ cells/mg; $P=0.201$ ) (Figure 4D). The low number of F4/ $80^{\mathrm{Hi}}$ macrophages in the diaphragm samples prevented comparison to C57 quadriceps for downstream markers.

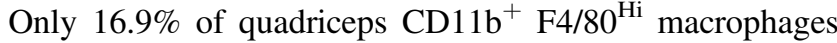
expressed CD68, suggesting that CD68, although specific, might not be a good marker to characterize muscle macrophages.

$\mathrm{F} 4 / 80^{\mathrm{Hi}} \mathrm{CD}^{+} 8^{+}$macrophages from $\mathrm{C} 57$ quadriceps muscles were further characterized for CCR2, CD206, and
MHC II marker expression (Figure 4E). We chose these phenotypic markers because CCR2 is a chemokine required for immune cell infiltration into the tissues, CD206 ${ }^{+} \mathrm{M} 2$ like macrophages are reparative and profibrotic, and high MHC II reflects antigen-presenting cells. Most (66.2\%) of the $\mathrm{CD}^{+} 5^{+} \mathrm{CD}_{11 b^{+}} \mathrm{LY}^{-} \mathrm{G}^{-} \mathrm{F} 4 / 80^{\mathrm{Hi}} \mathrm{CD}^{+}$cells expressed the M2-like marker CD206, but a similar percentage $(67.6 \%)$ of $\mathrm{F} 4 / 80^{\mathrm{Hi}} \mathrm{CD}^{-} 8^{-}$cells also had CD206. This similar cell surface expression of CD206 in the CD68population further supports the presence of macrophages without cell surface expression of CD68. More important, only $41.2 \%$ of $\mathrm{F} 4 / 80^{\mathrm{Hi}} \mathrm{CD}^{+} 8^{+}$macrophages expressed CCR2, whereas the majority did not, establishing the presence of two different subsets of macrophages in this population. Only $20.7 \%$ of $\mathrm{F} 4 / 80^{\mathrm{Hi}} \mathrm{CD}^{+} 8^{+}$macrophages expressed cell surface MHC II.

Quadriceps from Het Mice Contain Significantly Higher Proportions of Neutrophils and Infiltrating Monocytes Compared with Mdx Mice

Het skeletal muscle has greater levels of fibrosis than $m d x$ skeletal muscle. We hypothesized that Het skeletal muscles would have increased or altered populations of infiltrated circulating leukocytes compared with $m d x$ throughout the early phase of injury at 4 weeks of age. To identify differences in immune cell subsets, their frequencies were compared as a percentage of total $\mathrm{CD} 45^{+}$leukocytes. Representative dot plots for described significant differences are displayed in Figure $5 \mathrm{~A}$. $\mathrm{LY} 6 \mathrm{G}^{+}$neutrophils and $\mathrm{LY} 6 \mathrm{C}^{\mathrm{Hi}}$ infiltrating monocytes were significantly increased [ $t$-test; 
$12.2 \% \pm 2.0 \%$ versus $4.7 \% \pm 0.6 \%(P=0.004)$ and $25.7 \% \pm 2.0 \%$ versus $15.8 \% \pm 2.9 \%(P=0.017)$, respectively] in the quadriceps of Het mice compared with the $m d x$ mice (Figure 5C). These populations were also trending higher in Het diaphragms relative to $m d x$ diaphragms, although the data were not significant because of the overall lower numbers of diaphragm inflammatory cells (neutrophils: $P=0.270$; infiltrating monocytes: $P=0.070)$. Slightly higher total numbers of neutrophils and $\mathrm{LY}_{6 \mathrm{C}} \mathrm{Hi}^{\mathrm{Hi}}$ infiltrating monocytes were also present in the quadriceps and diaphragms of Het mice compared with $m d x$ mice (Figure 5B). These changes, however, were not significant because of high variability observed in immune cell numbers for both genotypes. This variability also indicates that all the mice may not have an equivalent degree of injury at the chosen time point and may have slight differences in their time course of immune cell activation/infiltration. Because both neutrophils and $\mathrm{LY} 6 \mathrm{C}^{\mathrm{Hi}}$ monocytes are early responders of tissue injury, their higher frequencies in the Het mice reflect an ongoing early-phase inflammatory response. It is, therefore, possible that although $m d x$ mice were at the peak of their inflammatory response at 4 weeks of age, Het mice were still undergoing early tissue remodeling and might exhibit peak inflammatory response at a different time scale given their more severe pathology.

Because the inflammatory state in dystrophic muscle is severe, we predicted a large proportion of myeloid F4/ $80^{\mathrm{Hi} / \mathrm{Lo}}$ cells would express extracellular CD68. However, no significant differences in the proportions of $\mathrm{F} 4 / 80^{\mathrm{Hi} / \mathrm{Lo}}$ $\mathrm{CD}^{+} 8^{+}$macrophages or LY6C ${ }^{\mathrm{Lo}}$ patrolling monocytes were present between Het and $m d x$ quadriceps or diaphragms. These cells compose a small percentage of the total CD $45^{+}$ immune cell population in both genotypes and tissues. Quadriceps from both genotypes had $7 \%$ to $8 \% \mathrm{~F} 4 / 80^{\mathrm{Hi}}$ $\mathrm{CD}^{+} 8^{+}$and approximately $2 \% \mathrm{~F} 4 / 80^{\mathrm{Lo}} \mathrm{CD} 68^{+}$cells and diaphragms had $3 \%$ to $4 \% \mathrm{~F} 4 / 80^{\mathrm{Hi}} \mathrm{CD}^{+} 8^{+}$and approximately $4 \%$ to $5 \% \mathrm{~F} 4 / 80^{\mathrm{Lo}} \mathrm{CD}^{+} 8^{+}$cells. More importantly, macrophages expressing high levels of F4/80 (7\% to $8 \%$ of total $\mathrm{CD} 45^{+}$cells) were not different between both dystrophic genotypes in quadriceps. However, $m d x$ diaphragm F4/ $80^{\mathrm{Hi}}$ macrophages were more M2 like, and $24.1 \% \pm 3.7 \%$ of $\mathrm{F} 4 / 80^{\mathrm{Hi}}$ macrophages expressed CD206, compared with only $10.5 \% \pm 1.3 \%(P=0.026)$ in Het mice (Figure $5 \mathrm{D})$. The opposite is true for M1-like CD206 ${ }^{-}$macrophages, which were present at much higher percentages in Het mice compared with $m d x$ mice $(75.9 \%$ and $89.5 \%$, respectively), again suggesting an active proinflammatory phase in this genotype.

\section{Het Quadriceps and Diaphragms Display Tissue-Specific Differences in Myeloid Cell Composition}

Although all skeletal muscles have evolved the ability to regenerate, whether differences in the immune response between dystrophic limb and respiratory muscles would provide insight into why certain muscles have accelerated pathology in DMD was investigated. Because dystrophic diaphragms accumulate more fibrosis than quadriceps muscles and lose regenerative capacity earlier, diaphragm and quadriceps immune cell profiles from Het mice were compared. Het quadriceps show a nonsignificant trend for higher immune cell density than diaphragms for all the populations examined (Figure 6A). However, Het quadriceps have a significantly higher percentage of myeloid cells than diaphragms $(94.8 \% \pm 0.4 \%$ versus $90.2 \% \pm 1.0 \%, t$ test; $P=0.001)$. Quadriceps from Het mice also contained a significantly lower percentage of $\mathrm{F} 4 / 80^{\mathrm{Lo}} \mathrm{CD} 68^{+}$macrophages $(1.9 \% \pm 0.3 \%$ versus $5.4 \% \pm 1.2 \% ; P=0.001)$ and patrolling monocytes $(4.2 \% \pm 0.3 \%$ versus $7.4 \% \pm 0.6 \%$; $P=0.008$ ) than diaphragms (Figure 6B). When performing phenotypic analysis on both populations of macrophages, no differences in marker expression were found (Figure 6, C and D).

Because extracellular CD68 ${ }^{+}$appears only to be present on a subset of macrophages, Het quadriceps and diaphragm $\mathrm{F} 4 / 80^{\mathrm{Hi} / \mathrm{Lo}}$ populations were examined in total $\mathrm{CD} 11 \mathrm{~b}^{+}$cells without gating for CD68. Het quadriceps contained a significantly higher percentage of $\mathrm{F} 4 / 80^{\mathrm{Hi}}$ macrophages $(38.7 \% \pm 3.1 \%$ versus $14.9 \% \pm 2.1 \% ; P=0.002)$ and trended higher in cell numbers $(P=0.138)$ (Figure 6, E and F). Het quadriceps also contained a significantly lower percentage of $\mathrm{F} 4 / 80^{\mathrm{Lo}}$ monocytes compared with Het diaphragms $(43.4 \% \pm 2.2 \%$ versus $58.3 \% \pm 5.0 \%$; $P=0.014)$.

\section{Het Quadriceps $\mathrm{F} 4 / 80^{\mathrm{Hi}} \mathrm{CCR}^{+}$Macrophages Are M2 Like, Profibrotic, and Proinflammatory}

CD206 was also assessed in each myeloid cell population from cytometry experiments to determine which populations were more M2 like. CD206 cell surface expression was enriched in $\mathrm{CCR}^{+}(26.9 \%)$ and $\mathrm{F} 4 / 80^{\mathrm{Hi}}(18.5 \%)$ macrophages, with much lower expression in the CCR2 ${ }^{-}(5.6 \%)$ and $\mathrm{F} 4 / 80^{\mathrm{Lo}}(1.5 \%)$ populations. Enrichment of CD206 levels in $\mathrm{F} 4 / 80^{\mathrm{Hi}} \mathrm{CCR} 2^{+}$macrophages was also validated by t-distributed stochastic neighbor embedding dimensionality reduction (Figure 7).

To quantify gene expression in a cell-specific manner and confirm flow cytometry results, four myeloid cell populations were isolated using fluorescently activated cell sorting from $m d x$ and Het quadriceps muscles, and gene expression was analyzed using droplet digital PCR. The four sorted populations included the following: infiltrating monocytes $\left(\mathrm{CD} 45^{+} \mathrm{CD}_{11 b^{+}} \mathrm{LY} 6 \mathrm{G}^{-} \mathrm{F} / 80^{\mathrm{Lo}} \mathrm{LY}^{\mathrm{Hi}} \mathrm{C}^{\mathrm{Hi}}\right.$, patrolling monocytes $\left(\mathrm{CD} 45^{+} \mathrm{CD} 11 \mathrm{~b}^{+} \mathrm{LY} 6 \mathrm{G}^{-} \mathrm{F} 4 / 80^{\mathrm{Lo}}\right.$ $\left.\mathrm{LY}_{6 \mathrm{C}}{ }^{-/ \mathrm{Lo}}\right), \quad \mathrm{F} 4 / 80^{\mathrm{Hi}} \mathrm{CCR}^{+}$macrophages $\left(\mathrm{CD} 45^{+}\right.$ $\mathrm{CD}_{11 b^{+}} \mathrm{LY}_{6 \mathrm{G}^{-}} \mathrm{F} 4 / 80^{\mathrm{Hi}} \mathrm{CCR}^{+}$), and $\mathrm{F} 4 / 80^{\mathrm{Hi}} \mathrm{CCR}^{-}$

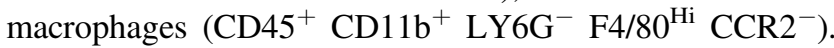
The gene expression of several M1-like and M2-like markers, including Mrcl (CD206), Colla (collagen I), Spp1 (osteopontin), Nos2 (inducible nitric oxide synthase), and Timd4, was compared between the described 
Table $2 M d x$ and Het Comparison of Target Copies per Nanogram of RNA Isolated from Quadriceps CD45 ${ }^{+} \mathrm{CD}_{11 b^{+}} \mathrm{LY}_{6 \mathrm{G}}{ }^{-} \mathrm{F} 4 / 80^{\mathrm{Lo}} \mathrm{LY} \mathrm{C}^{\mathrm{Hi}}$

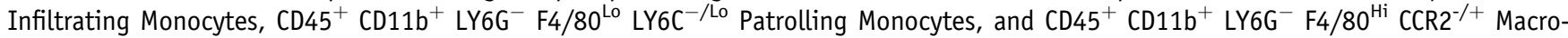
phages, Including $t$-Test Significance Values

\begin{tabular}{|c|c|c|c|c|c|c|}
\hline \multirow[b]{2}{*}{ Target } & \multicolumn{3}{|c|}{$\mathrm{F} 4 / 80^{\text {Lo }} \mathrm{LY} 6 \mathrm{C}^{-/ \mathrm{Lo}}$} & \multicolumn{3}{|c|}{$\mathrm{F} 4 / 80^{\mathrm{Lo}} \mathrm{LY} 6 \mathrm{C}^{\mathrm{Hi}}$} \\
\hline & $M d x$ & Het & $P$ value & $M d x$ & Het & $P$ value \\
\hline Mrc1 & $0.07 \pm 0.02$ & $3.67 \pm 1.05$ & 0.026 & $0.02 \pm 0.02$ & $0.31 \pm 0.20$ & 0.222 \\
\hline Spp1 & $45.69 \pm 17.06$ & $4188 \pm 829.83$ & 0.007 & $3.78 \pm 3.32$ & $212 \pm 138.58$ & 0.207 \\
\hline Nos2 & $0 \pm 0$ & $1.64 \pm 0.29$ & 0.004 & $0 \pm 0$ & $0.36 \pm 0.36$ & 0.373 \\
\hline Timd4 & $0 \pm 0$ & $4.27 \pm 4.27$ & 0.373 & $1.07 \pm 1.07$ & $4.93 \pm 4.93$ & $\begin{array}{r}0.486 \\
\text { (table continues) }\end{array}$ \\
\hline
\end{tabular}

Summary values are presented as means \pm SEM copies/ng RNA. Targets quantified using droplet digital PCR include the following: Mrc1, Col1a, Spp1, Nos2, and Timd4.

populations isolated from $m d x$ and Het quadriceps (Table 2). Abundance of Mrcl, Timd4, and Nos2 transcripts were low in all cell populations, particularly in comparison to Colla and Sppl expression. Overall, $\mathrm{F} 4 / 80^{\mathrm{Hi}} \mathrm{CCR}^{+}$macrophages expressed the highest levels of all transcripts. Among the two genotypes, Het patrolling monocytes expressed significantly higher $\mathrm{Mrcl}$ (3.67 \pm 1.05 versus $0.07 \pm 0.02$ copies/ng RNA; $t$-test; $P=0.026)$, Colla $(738.67 \pm 248.2$ versus $41.33 \pm 8.33$ copies/ng RNA; $P=0.048)$, Sppl $(4188 \pm 829.83$ versus $45.69 \pm 17.06$ copies/ng RNA; $P=0.007$ ), and Nos2 $(1.64 \pm 0.29$ versus 0 copies/ng RNA; $P=0.004)$ than $m d x$ derived cells, whereas Het infiltrating monocytes expressed significantly higher Colla $(42.13 \pm 9.67$ versus $3.42 \pm 1.54$ copies/ng RNA; $P=0.016$ ). In $\mathrm{Het} \mathrm{F} 4 / 80^{\mathrm{Hi}} \mathrm{CCR} 2^{+}$macrophages, Nos 2 expression was significantly up-regulated $(17.11 \pm 1.46$ versus $5.87 \pm 3.07$ copies/ng RNA; $P=0.029) . \operatorname{Mrcl}(P=0.083)$ and Colla $(P=0.104)$ trended higher in gene expression in $\mathrm{Het} \mathrm{F} 4 / 80^{\mathrm{Hi}} \mathrm{CCR} 2^{+}$macrophages compared with $m d x$.

When comparing gene expression between $\mathrm{F} 4 / 80^{\mathrm{Hi}}$ $\mathrm{CCR}^{+}$macrophages with the other three Het quadriceps populations (Table 3), $\mathrm{F} 4 / 80^{\mathrm{Hi}} \mathrm{CCR}^{+}$macrophages expressed significantly higher $M r c l$ (one-way analysis of variance; Benjamini/Krieger/Yekutieli; $P \leq 0.05$ ) than patrolling monocytes $(13.1 \pm 5.13$ versus $3.67 \pm 1.05$; $P=0.034)$, infiltrating monocytes $(0.31 \pm 0.20$ copies $/ \mathrm{ng}$ RNA; $P=0.008$ ), and $\mathrm{F} 4 / 80^{\mathrm{Hi}} \mathrm{CCR} 2^{-}$macrophages $(0.19 \pm 0.13$ copies/ng RNA; $P=0.008)$, confirming the flow cytometry data showing higher frequency of CD206 ${ }^{+}$ cells in this population. In addition, Colla expression was significantly higher in $\mathrm{F} 4 / 80^{\mathrm{Hi}} \mathrm{CCR} 2^{+}$macrophages relative to patrolling monocytes $(5565.33 \pm 2543.17$ versus $738.67 \pm 248.20 ; P=0.039)$, infiltrating monocytes $(42.13 \pm 9.67$ copies/ng RNA; $P=0.032)$, and $\mathrm{F} 4 / 80^{\mathrm{Hi}}$ CCR2 ${ }^{-}$macrophages $(24.67 \pm 13.21$ copies/ng RNA; $P=0.032$ ). A similar trend was seen in Sppl; however, there was no significant difference between mean target expression in the populations $(P=0.181)$. The $\mathrm{F} 4 / 80^{\mathrm{Hi}}$ $\mathrm{CCR}^{+}$macrophages also expressed significantly higher Nos 2 than all the other Het quadriceps-derived populations $(17.11 \pm 1.46$ versus $1.64 \pm 0.29,0.36 \pm 0.36$, and 0 copies/ng RNA; $P<0.001$ ). Phagocytic marker Timd4 expression was not different in any of the populations or genotypes $(P=0.903)$.

Table 3 Intragenotype Comparison of Gene Expression between the Described Populations Isolated from Het Quadriceps, including OneWay ANOVA and B.K.Y. Multicomparison Significance Values Comparing F4/80 ${ }^{\mathrm{Hi}} \mathrm{CCR}^{+}$Macrophages with the 0ther Isolated Cells

\begin{tabular}{|c|c|c|c|c|c|c|}
\hline \multirow[b]{2}{*}{ Population } & \multicolumn{3}{|l|}{ Mrc1 } & \multicolumn{3}{|l|}{ Col1a } \\
\hline & Het & ANOVA & B.K.Y. & Het & ANOVA & B.K.Y. \\
\hline F4/80 ${ }^{\text {Lo }} \mathrm{LY} 6 \mathrm{C}^{-/ \mathrm{Lo}}$ & $3.67 \pm 1.05$ & 0.025 & 0.034 & $738.67 \pm 248.20$ & 0.042 & 0.039 \\
\hline $\mathrm{F} 4 / 80^{\mathrm{LO}} \mathrm{LY}_{6 \mathrm{C}^{\mathrm{Hi}}}$ & $0.31 \pm 0.20$ & & 0.008 & $42.13 \pm 9.67$ & & 0.032 \\
\hline $\mathrm{F} 4 / 80^{\mathrm{Hi}} \mathrm{CCR}^{-}$ & $0.19 \pm 0.13$ & & 0.008 & $24.67 \pm 13.21$ & & 0.032 \\
\hline $\mathrm{F} 4 / 80^{\mathrm{Hi}} \mathrm{CCR}^{+}$ & $13.1 \pm 5.13$ & & * & $5565.33 \pm 2543.17$ & & * \\
\hline
\end{tabular}

(table continues)

Summary values are presented as means \pm SEM copies/ng RNA.

${ }^{*} \mathrm{~F} 4 / 80^{\mathrm{Hi}} \mathrm{CCR}^{+}$macrophages.

ANOVA, analysis of variance; B.K.Y., Benjamini/Krieger/Yekutieli. 
Table 2 (continued)

\begin{tabular}{|c|c|c|c|c|c|}
\hline \multicolumn{3}{|l|}{$\mathrm{F} / 80^{\mathrm{Hi}} \mathrm{CCR}^{-}$} & \multicolumn{3}{|l|}{$\mathrm{F}_{4} / 80^{\mathrm{Hi}} \mathrm{CCR}^{+}$} \\
\hline$M d x$ & Het & $P$ value & $M d x$ & Het & $P$ value \\
\hline $0.5 \pm 0.31$ & $0.19 \pm 0.13$ & 0.408 & $1.23 \pm 0.66$ & $13.1 \pm 5.13$ & 0.083 \\
\hline $110.76 \pm 53.27$ & $81.33 \pm 43.35$ & 0.690 & $316.44 \pm 211.57$ & $12,225.33 \pm 7850.59$ & 0.204 \\
\hline $0 \pm 0$ & $0 \pm 0$ & N.A. & $5.87 \pm 3.07$ & $17.11 \pm 1.46$ & 0.029 \\
\hline $0.93 \pm 0.93$ & $2 \pm 2$ & 0.652 & $0 \pm 0$ & $5.87 \pm 3.47$ & 0.165 \\
\hline
\end{tabular}

\section{Discussion}

In this study, a variety of techniques were utilized to characterize resident immune cells in healthy mouse skeletal muscle and quantify differences in skeletal muscle inflammation between two dystrophic mouse models, $m d x$ and Het, with increasing severity. Presence of cytokines in C57 wild-type quadriceps indicates a continuous maintenance of resident immune cell populations in healthy skeletal muscle. Het skeletal muscle contained increased protein levels of numerous chemokines relative to $m d x$ skeletal muscle, and gene expression cytokines and chemokine receptors identified a peak inflammatory phase at 4 weeks of age in both models and tissues. These data support what has previously been shown in the $m d x$ model with an early peak in myofiber damage and inflammation, which appears to also occur in Het skeletal muscle. ${ }^{3,6}$

Increased $C c l 2$ and $T n f$ gene expression in Het relative to $m d x$ quadriceps early in pathology corresponds to the increased recruitment of monocytes and neutrophils due to elevated damage, as well as an M1 bias in the macrophages present in the tissue observed in the flow cytometry results. Het diaphragms contained significantly higher expression of Ccr5 and Tnf compared with Het quadriceps, which may represent differences in monocyte or lymphocyte recruitment between limb and respiratory muscles. Infiltrating monocytes and neutrophils primarily follow CCL2 gradients via CCR2 to extravasate into damaged tissues, including skeletal muscle. $^{43} \mathrm{~F} 4 / 80^{\mathrm{Hi}}$ macrophages in Het diaphragms are also more M1 like than in $m d x$ diaphragms, which likely promotes myofiber cytotoxicity and may contribute to the higher levels of fibrosis in diaphragms. ${ }^{7}$ These results cumulatively indicate that Het skeletal muscle contains more inflammatory signaling than $m d x$ skeletal muscle early in pathology, but like the $m d x$ tissues, inflammation dampens as pathology progresses. Het skeletal muscle likely undergoes more necrosis during the early (4-week) phase of dystrophic mouse pathology because the sarcolemma is more vulnerable to contraction-induced damage without the partial compensation from reduced utrophin levels. Het skeletal muscle also displays more significant $I l l b$ and $I l 6$ up-regulation relative to C57, which indicates that Het shares more similarities with human DMD in terms of inflammatory markers. ${ }^{3}$

Immune cell isolation from dystrophic skeletal muscle has traditionally involved usage of density-dependent centrifugation to enrich for immune cells and remove tissue debris. Both histopaque and lympholyte are ficoll-like polysaccharide solutions optimized for isolating peripheral blood mononuclear cells from an interface, ${ }^{21,38,39}$ but their efficiency for isolating immune cells after extravasation into

Table 3 (continued)

\begin{tabular}{|c|c|c|c|c|c|}
\hline \multicolumn{3}{|l|}{ Spp1 } & \multicolumn{3}{|l|}{ Nos2 } \\
\hline $4188 \pm 829.83$ & 0.181 & 0.187 & $1.64 \pm 0.29$ & $<0.001$ & $<0.001$ \\
\hline $81.33 \pm 43.35$ & & 0.061 & $0 \pm 0$ & & $<0.001$ \\
\hline $12,225.33 \pm 7850.59$ & & * & $17.11 \pm 1.46$ & & * \\
\hline
\end{tabular}


muscle tissues had not previously been quantified. Herein, we demonstrate increased size and granularity of immune cells from dystrophic skeletal muscle compared with blood and that muscle myeloid cells are lost in histopaque and lympholyte pellets. The direct isolation method and CD $45^{+}$ back gating increase yield of total and specific cell populations and enable analysis of individual muscle types from one or two mice instead of previous pooling of multiple muscle types or of muscles from large numbers of animals.

Monocytes express low levels of F4/80 in the blood, and macrophages derived from monocytes also tend to express low levels of F4/80. ${ }^{23}$ Macrophages further along in differentiation are found to express higher levels of F4/80, but this process has not been demonstrated in skeletal muscle. ${ }^{44}$ In dystrophic studies, $\mathrm{F} 4 / 80^{\mathrm{Lo} / \mathrm{Hi}}$ expression has been used to identify M1 and M2 macrophages, respectively, but our data support that expression of this marker may be more appropriate for visualizing the spectrum of states during the monocyte to macrophage differentiation process. It is possible that circulating cells present in capillaries supplying blood to the muscle-tissues were detected in our studies. However, this result is unlikely for two reasons. First, circulating monocytes do not have high expression of F4/ $80{ }^{44}$ Second, $\mathrm{CD} 1 \mathrm{~b}^{+}$myeloid cells represent only approximately $15 \%$ to $18 \%$ of total CD $45^{+}$leukocytes in the blood. In contrast, approximately $90 \%$ of $\mathrm{CD}^{+} 5^{+}$leukocytes were $\mathrm{CD}_{11 b^{+}}$cells in our muscle digests, suggesting that the $m d x /$ Het muscles were selectively enriched with myeloid cells and the inclusion of capillary entrapped leukocytes was minimal in our studies. We hypothesized that cell surface CD68 and F4/80 expression would enable us to discriminate activated macrophages from monocytes, dendritic cells, and granulocytes in flow cytometry experiments.

Healthy mouse quadriceps, and to a lesser extent diaphragm, contain a population of $\mathrm{CD} 45^{+} \mathrm{CD} 11 \mathrm{~b}^{+} \mathrm{LY} 6 \mathrm{G}^{-}$ $\mathrm{F} 4 / 80^{\mathrm{Hi}}$ cells that contain minimal extracellular CD68, but $>60 \%$ of $\mathrm{CD}_{4} 5^{+} \mathrm{CD} 45^{+} \mathrm{CD} 11 \mathrm{~b}^{+} \mathrm{LY} 6 \mathrm{G}^{-} \mathrm{F} 4 / 80^{\mathrm{Hi}} \mathrm{CD} 68^{+}$ wild-type quadriceps macrophages express CD206. Because CD68 appears on the cell surface of only a small percentage of macrophages, it is possible that both intracellular and extracellular CD68 staining may more appropriately label all the macrophage populations. Resident skeletal muscle macrophages may suppress inflammation to a minimal level required for efficient tissue repair following injury. Alternative markers, such as CD64, shown to be expressed on macrophages, may be more informative for further differentiation between macrophages in future studies. ${ }^{45}$

One of the primary causes of death in DMD patients is respiratory failure, resulting from diaphragm dysfunction. Quadriceps experience a larger range of contractile forces and are susceptible to external injuries that may require a more complex and sophisticated immunologic response to regulate regeneration and dampen detrimental inflammation. Het quadriceps were found to have a higher percentage of myeloid cells, but lower percentages of $\mathrm{F} 4 / 80^{\mathrm{Lo}}$ macrophages and
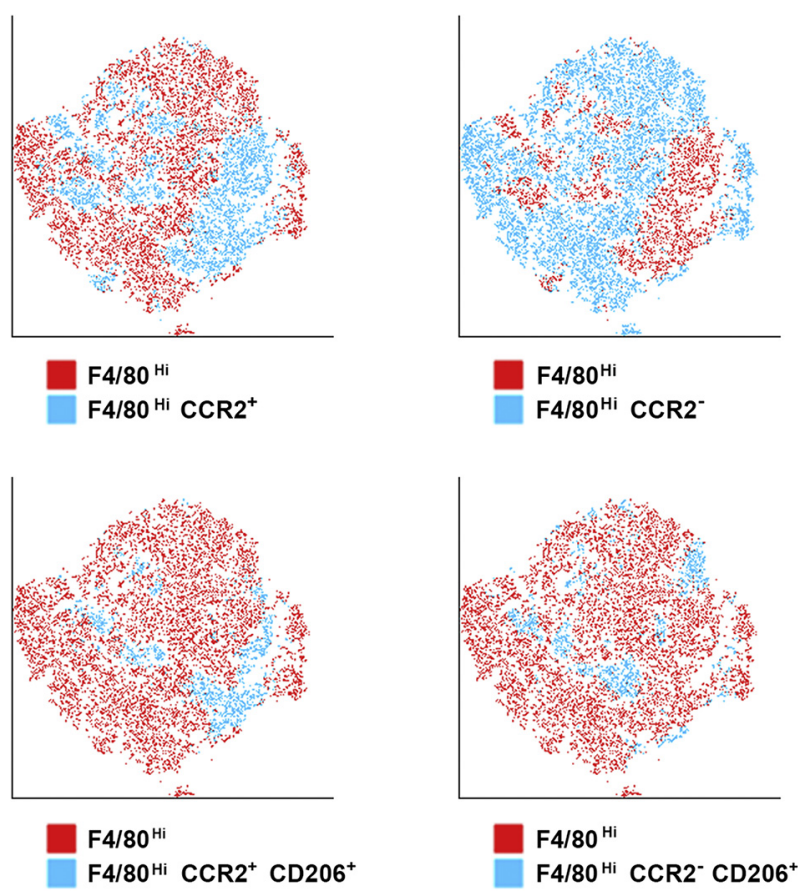

Figure 7 t-Distributed stochastic neighbor embedding (tSNE) dimensionality reduction of Het quadriceps $\mathrm{CD}_{4} 5^{+} \mathrm{CD}_{11 b^{+}} \mathrm{LY}_{6 \mathrm{G}}{ }^{-} \mathrm{F} 4 / 80^{\mathrm{Hi}}$ cells (red) to show the distribution of $\mathrm{CD}_{4} 5^{+} \mathrm{CD}_{11 b^{+}} \mathrm{LY}_{6 \mathrm{G}}{ }^{-} \mathrm{F} 4 / 80^{\mathrm{Hi}} \mathrm{CCR}^{+/-}$ CD206 $^{+}$cells (blue).

patrolling monocytes than Het diaphragms, with an even greater difference observed when not further gating for CD68. Because wild-type diaphragms do not have a significant F4/ $80^{\mathrm{Hi}}$ macrophage population to expand with chronic tissue injury, macrophages derived from circulating $\mathrm{F} 4 / 80^{\mathrm{Lo}}$ monocytes may be more abundant in this tissue. Patrolling monocytes may play a role in early dystrophic fibrosis because these cells have been shown to be promote pathology in other diseases that end in tissue dysfunction. ${ }^{46,47}$ Interestingly, both $\mathrm{F} 4 / 80^{\mathrm{Lo}}$ and $\mathrm{F} 4 / 80^{\mathrm{Hi}}$ macrophage marker expression was not different between tissues, which may suggest that the downstream responses of the differentiated macrophages reach homeostasis, but the origins and amplitude of the myelogenous response are dysregulated.

The roles of $\mathrm{CCR}^{+}$myeloid cells may be tissuedependent. CCR2 levels in cardiac macrophages are associated with proinflammatory signaling, but macrophages expressing CCR2 and $\mathrm{F} 4 / 80^{\mathrm{Hi}}$ are enriched for the M2-like marker CD206. ${ }^{31}$ These cells also play a role in angiogenesis. ${ }^{48}$ Because Het myofibers undergo more damage due to the reduction of utrophin for mechanical reinforcement of the sarcolemma, myeloid cell up-regulation of Colla and Spp1 early in pathology is likely required for efficient regeneration. Identical cell populations isolated from both genotypes are more transcriptionally active in Het muscle to mitigate more damage. Elevated COL1A and osteopontin in dystrophic muscle and serum have been shown to hasten development of fibrosis in response to severe myofiber 
damage. ${ }^{21,23,49}$ In addition, Het $\mathrm{F} 4 / 80^{\mathrm{Hi}} \mathrm{CCR} 2^{+}$macrophages are enriched in expression of these targets relative to the other myeloid populations isolated from the same genotype. These macrophages paradoxically expressed the most Mrcl and Nos2, which are markers for M2-like and M1-like macrophages, respectively. F4/80 ${ }^{\mathrm{Hi}} \mathrm{CCR} 2^{+}$macrophages are likely composed of different M2 macrophage subtypes, involved in both suppressing inflammation and promoting fibrosis through Colla and Sppl expression. ${ }^{50}$ Diaphragms, which contain a smaller quantity of $\mathrm{F} 4 / 80^{\mathrm{Hi}}$ macrophages, may develop accelerated fibrosis through the increased infiltration of $\mathrm{F} 4 / 80^{\mathrm{Lo}}$ monocyte-derived macrophages, as well as the activity of fibrocytes, which are likely present in the patrolling monocyte/LY6C ${ }^{-/ L o}$ population based on their high Colla expression relative to the infiltrating monocytes. ${ }^{21,23}$

Although it is unclear from the data whether the inflammatory differences are consequences or determinants of disease severity between the two models, the enhanced immune response in Het skeletal muscle is likely a necessary consequence of more muscle damage, albeit the increased infiltration may be more harmful than beneficial. Infiltration of $\mathrm{CCR} 2^{+} \mathrm{LY}_{6} \mathrm{C}^{\mathrm{Hi}}$ monocytes and differentiation into various macrophage subtypes are required for efficient regeneration during acute or chronic skeletal muscle injury ${ }^{51,52}$; however, infiltration of $\mathrm{CCR} 2^{+}$macrophages after cardiac injury promotes tissue fibrosis and dysfunction. ${ }^{31}$ More infiltration of $\mathrm{CCR}^{+} \mathrm{LY}_{6 \mathrm{C}}{ }^{\mathrm{Hi}}$ monocytes in Het skeletal muscle may increase the rate at which the regenerative potential of the tissue diminishes, occurring earlier in diaphragms than in quadriceps. Het quadriceps and diaphragms, during the early phase of murine dystrophic pathology, exhibit similar but different inflammatory responses that likely limit diaphragm regenerative potential, resulting in a more rapid accumulation of fibrosis. $\mathrm{F} 4 / 80^{\mathrm{Hi}}$ macrophages may be important for mediating an efficient regenerative response in limb muscles, which are subject to mechanical and exercisebased injuries. The lack of environmental pressures on diaphragm muscle to evolve a more robust immunemediated regenerative response may correlate with the lower resident $\mathrm{F} 4 / 80^{\mathrm{Hi}}$ macrophage density observed and the capacity to mitigate myofiber damage.

Early-onset inflammation in skeletal and cardiac muscle correlates with poor clinical outcomes in DMD, including loss of ambulation and heart failure. ${ }^{53-55}$ Inflammationinduced skeletal muscle fibrosis has even been shown in female carriers of DMD ${ }^{56}$ Future studies, beyond the scope of the current study, will be needed to more thoroughly characterize DMD myeloid cells. Understanding the tissuespecific, temporal functions of myeloid cells in dystrophic muscle will be important for developing targeted immunomodulatory therapies to improve quality of life and lifespan in DMD patients. Anti-inflammatory treatments synergistic with emerging genetic therapies are expected to provide the best possible outcomes for DMD patients.

\section{Acknowledgment}

We thank Bryan McElwain from the Flow Cytometry Shared Resource.

\section{Supplemental Data}

Supplemental material for this article can be found at http://doi.org/10.1016/j.ajpath.2021.01.008.

\section{References}

1. Hoffman EP, Brown RH Jr, Kunkel LM, Dystrophin: the protein product of the Duchenne muscular dystrophy locus. Cell 1987, 51: 919-928

2. Miyatake S, Shimizu-Motohashi Y, Takeda S, Aoki Y: Anti-inflammatory drugs for Duchenne muscular dystrophy: focus on skeletal muscle-releasing factors. Drug Des Devel Ther 2016, 10:2745-2758

3. Rosenberg AS, Puig M, Nagaraju K, Hoffman EP, Villalta SA, Rao VA, Wakefield LM, Woodcock J: Immune-mediated pathology in Duchenne muscular dystrophy. Sci Transl Med 2015, 7:299rv4

4. De Rossi M, Bernasconi P, Baggi F, de Waal Malefyt R, Mantegazza R: Cytokines and chemokines are both expressed by human myoblasts: possible relevance for the immune pathogenesis of muscle inflammation. Int Immunol 2000, 12:1329-1335

5. Cannon JG, St Pierre BA: Cytokines in exertion-induced skeletal muscle injury. Mol Cell Biochem 1998, 179:159-167

6. Villalta SA, Nguyen HX, Deng B, Gotoh T, Tidball JG: Shifts in macrophage phenotypes and macrophage competition for arginine metabolism affect the severity of muscle pathology in muscular dystrophy. Hum Mol Genet 2009, 18:482-496

7. Zhou L, Rafael-Fortney JA, Huang P, Zhao XS, Cheng G, Zhou X, Kaminski HJ, Liu L, Ransohoff RM: Haploinsufficiency of utrophin gene worsens skeletal muscle inflammation and fibrosis in mdx mice. J Neurol Sci 2008, 264:106-111

8. Fenichel GM, Florence JM, Pestronk A, Mendell JR, Moxley RT 3rd, Griggs RC, Brooke MH, Miller JP, Robison J, King W, Signore L, Pandya S, Schierbecker J, Wilson B: Long-term benefit from prednisone therapy in Duchenne muscular dystrophy. Neurology 1991, 41:1874-1877

9. Mescher AL, Neff AW, King MW: Inflammation and immunity in organ regeneration. Dev Comp Immunol 2017, 66:98-110

10. Cordero-Espinoza L, Huch M: The balancing act of the liver: tissue regeneration versus fibrosis. J Clin Invest 2018, 128:85-96

11. Karin M, Clevers H: Reparative inflammation takes charge of tissue regeneration. Nature 2016, 529:307-315

12. Brigitte M, Schilte C, Plonquet A, Baba-Amer Y, Henri A, Charlier C, Tajbakhsh S, Albert M, Gherardi RK, Chrétien F: Muscle resident macrophages control the immune cell reaction in a mouse model of notexin-induced myoinjury. Arthritis Rheum 2010, 62: 268-279

13. Spencer MJ, Montecino-Rodriguez E, Dorshkind K, Tidball JG: Helper $(\mathrm{CD} 4(+))$ and cytotoxic $(\mathrm{CD} 8(+)) \mathrm{T}$ cells promote the pathology of dystrophin-deficient muscle. Clin Immunol 2001, 98: $235-243$

14. Tidball JG, Welc SS, Wehling-Henricks M: Immunobiology of inherited muscular dystrophies. Compr Physiol 2018, 8:1313-1356

15. Kranig SA, Tschada R, Braun M, Patry C, Pöschl J, Frommhold D, Hudalla H: Dystrophin deficiency promotes leukocyte recruitment in mdx mice. Pediatr Res 2019, 86:188-194

16. Rizzo G, Di Maggio R, Benedetti A, Morroni J, Bouche M, Lozanoska-Ochser B: Splenic Ly6Chi monocytes are critical players in dystrophic muscle injury and repair. JCI Insight 2020, 5:e130807 
17. Mojumdar K, Liang F, Giordano C, Lemaire C, Danialou G, Okazaki T, Bourdon J, Rafei M, Galipeau J, Divangahi M, Petrof BJ: Inflammatory monocytes promote progression of Duchenne muscular dystrophy and can be therapeutically targeted via CCR2. EMBO Mol Med 2014, 6:1476-1492

18. Hodgetts S, Radley H, Davies M, Grounds MD: Reduced necrosis of dystrophic muscle by depletion of host neutrophils, or blocking TNFalpha function with etanercept in mdx mice. Neuromuscul Disord 2006, 16:591-602

19. Mosser DM, Edwards JP: Exploring the full spectrum of macrophage activation. Nat Rev Immunol 2008, 8:958-969

20. Yang J, Zhang L, Yu C, Yang XF, Wang H: Monocyte and macrophage differentiation: circulation inflammatory monocyte as biomarker for inflammatory diseases. Biomark Res 2014, 2:1

21. Wang X, Zhao W, Ransohoff RM, Zhou L: Identification and function of fibrocytes in skeletal muscle injury repair and muscular dystrophy. J Immunol 2016, 197:4750-4761

22. Jakubzick CV, Randolph GJ, Henson PM: Monocyte differentiation and antigen-presenting functions. Nat Rev Immunol 2017, 17: 349-362

23. Capote J, Kramerova I, Martinez L, Vetrone S, Barton ER, Sweeney HL, Miceli MC, Spencer MJ: Osteopontin ablation ameliorates muscular dystrophy by shifting macrophages to a pro-regenerative phenotype. J Cell Biol 2016, 213:275-288

24. Acharyya S, Villalta SA, Bakkar N, Bupha-Intr T, Janssen PM, Carathers M, Li ZW, Beg AA, Ghosh S, Sahenk Z, Weinstein M, Gardner KL, Rafael-Fortney JA, Karin M, Tidball JG, Baldwin AS, Guttridge DC: Interplay of IKK/NF-kappaB signaling in macrophages and myofibers promotes muscle degeneration in Duchenne muscular dystrophy. J Clin Invest 2007, 117:889-901

25. Villalta SA, Deng B, Rinaldi C, Wehling-Henricks M, Tidball JG: IFN- $\gamma$ promotes muscle damage in the mdx mouse model of Duchenne muscular dystrophy by suppressing M2 macrophage activation and inhibiting muscle cell proliferation. J Immunol 2011, 187: $5419-5428$

26. Bencze M, Negroni E, Vallese D, Yacoub-Youssef H, Chaouch S, Wolff A, Aamiri A, Di Santo JP, Chazaud B, Butler-Browne G, Savino W, Mouly V, Riederer I: Proinflammatory macrophages enhance the regenerative capacity of human myoblasts by modifying their kinetics of proliferation and differentiation. Mol Ther 2012, 20: $2168-2179$

27. Saclier M, Cuvellier S, Magnan M, Mounier R, Chazaud B: Monocyte/macrophage interactions with myogenic precursor cells during skeletal muscle regeneration. FEBS J 2013, 280:4118-4130

28. Saclier M, Yacoub-Youssef H, Mackey AL, Arnold L, Ardjoune H, Magnan M, Sailhan F, Chelly J, Pavlath GK, Mounier R, Kjaer M, Chazaud B: Differentially activated macrophages orchestrate myogenic precursor cell fate during human skeletal muscle regeneration. Stem Cells 2013, 31:384-396

29. Desguerre I, Mayer M, Leturcq F, Barbet JP, Gherardi RK, Christov C: Endomysial fibrosis in Duchenne muscular dystrophy: a marker of poor outcome associated with macrophage alternative activation. J Neuropathol Exp Neurol 2009, 68:762-773

30. Epelman S, Lavine KJ, Beaudin AE, Sojka DK, Carrero JA, Calderon B, Brija T, Gautier EL, Ivanov S, Satpathy AT, Schilling JD, Schwendener R, Sergin I, Razani B, Forsberg EC, Yokoyama WM, Unanue ER, Colonna M, Randolph GJ, Mann DL: Embryonic and adult-derived resident cardiac macrophages are maintained through distinct mechanisms at steady state and during inflammation. Immunity 2014, 40:91-104

31. Bajpai G, Bredemeyer A, Li W, Zaitsev K, Koenig AL, Lokshina I, Mohan J, Ivey B, Hsiao HM, Weinheimer C, Kovacs A, Epelman S, Artyomov M, Kreisel D, Lavine KJ: Tissue resident CCR2- and CCR2 + cardiac macrophages differentially orchestrate monocyte recruitment and fate specification following myocardial injury. Circ Res 2019, 124:263-278
32. Epelman S, Lavine KJ, Randolph GJ: Origin and functions of tissue macrophages. Immunity 2014, 41:21-35

33. Committee for the Update of the Guide for the Care and Use of Laboratory Animals; National Research Council: Guide for the Care and Use of Laboratory Animals: Eighth Edition. Washington, DC, National Academies Press, 2011

34. Rafael-Fortney JA, Chimanji NS, Schill KE, Martin CD, Murray JD, Ganguly R, Stangland JE, Tran T, Xu Y, Canan BD, Mays TA, Delfín DA, Janssen PM, Raman SV: Early treatment with lisinopril and spironolactone preserves cardiac and skeletal muscle in Duchenne muscular dystrophy mice. Circulation 2011, 124:582-588

35. Lundberg I, Brengman JM, Engel AG: Analysis of cytokine expression in muscle in inflammatory myopathies, Duchenne dystrophy, and non-weak controls. J Neuroimmunol 1995, 63:9-16

36. Campanholle G, Mittelsteadt K, Nakagawa S, Kobayashi A, Lin SL, Gharib SA, Heinecke JW, Hamerman JA, Altemeier WA, Duffield JS: TLR-2/TLR-4 TREM-1 signaling pathway is dispensable in inflammatory myeloid cells during sterile kidney injury. PLoS One 2013, 8:e68640

37. Wehling M, Spencer MJ, Tidball JG: A nitric oxide synthase transgene ameliorates muscular dystrophy in mdx mice. J Cell Biol 2001, 155:123-131

38. Hightower RM, Reid AL, Gibbs DE, Wang Y, Widrick JJ, Kunkel LM, Kastenschmidt JM, Villalta SA, van Groen T, Chang H, Gornisiewicz S, Landesman Y, Tamir S, Alexander MS: The SINE compound KPT-350 blocks dystrophic pathologies in DMD zebrafish and mice. Mol Ther 2020, 28:189-201

39. Kastenschmidt JM, Avetyan I, Villalta SA: Characterization of the inflammatory response in dystrophic muscle using flow cytometry. Methods Mol Biol 2018, 1687:43-56

40. Covarrubias R, Ismahil MA, Rokosh G, Hamid T, Accornero F, Singh H, Gumina RJ, Prabhu SD, Bansal SS: Optimized protocols for isolation, fixation, and flow cytometric characterization of leukocytes in ischemic hearts. Am J Physiol Heart Circ Physiol 2019, 317: H658-H666

41. Bansal SS, Ismahil MA, Goel M, Zhou G, Rokosh G, Hamid T, Prabhu SD: Dysfunctional and proinflammatory regulatory T-lymphocytes are essential for adverse cardiac remodeling in ischemic cardiomyopathy. Circulation 2019, 139:206-221

42. Bansal SS, Ismahil MA, Goel M, Patel B, Hamid T, Rokosh G, Prabhu SD: Activated T lymphocytes are essential drivers of pathological remodeling in ischemic heart failure. Circ Heart Fail 2017, 10: e003688

43. Warren GL, Hulderman T, Mishra D, Gao X, Millecchia L, O'Farrell L, Kuziel WA, Simeonova PP: Chemokine receptor CCR2 involvement in skeletal muscle regeneration. FASEB J 2005, 19: $413-415$

44. Lee YS, Kim MH, Yi HS, Kim SY, Kim HH, Kim JH, Yeon JE, Byun KS, Byun JS, Jeong WI: CX(3)CR1 differentiates F4/80(low) monocytes into pro-inflammatory F4/80(high) macrophages in the liver. Sci Rep 2018, 8:15076

45. Tamoutounour S, Henri S, Lelouard H, de Bovis B, de Haar C, van der Woude CJ, Woltman AM, Reyal Y, Bonnet D, Sichien D, Bain CC, Mowat AM, Reis e Sousa C, Poulin LF, Malissen B, Guilliams M: CD64 distinguishes macrophages from dendritic cells in the gut and reveals the Th1-inducing role of mesenteric lymph node macrophages during colitis. Eur J Immunol 2012, 42: 3150-3166

46. Finsterbusch M, Hall P, Li A, Devi S, Westhorpe CL, Kitching AR, Hickey MJ: Patrolling monocytes promote intravascular neutrophil activation and glomerular injury in the acutely inflamed glomerulus. Proc Natl Acad Sci U S A 2016, 113:E5172-E5181

47. Combadière $\mathrm{C}$, Potteaux $\mathrm{S}$, Rodero $\mathrm{M}$, Simon $\mathrm{T}$, Pezard $\mathrm{A}$, Esposito B, Merval R, Proudfoot A, Tedgui A, Mallat Z: Combined inhibition of CCL2, CX3CR1, and CCR5 abrogates Ly6C(hi) and Ly6C(lo) monocytosis and almost abolishes atherosclerosis in hypercholesterolemic mice. Circulation 2008, 117:1649-1657 
48. Ochoa O, Sun D, Reyes-Reyna SM, Waite LL, Michalek JE, McManus LM, Shireman PK: Delayed angiogenesis and VEGF production in CCR2-/- mice during impaired skeletal muscle regeneration. Am J Physiol Regul Integr Comp Physiol 2007, 293: R651-R661

49. Kuraoka M, Kimura E, Nagata T, Okada T, Aoki Y, Tachimori H, Yonemoto N, Imamura M, Takeda S: Serum osteopontin as a novel biomarker for muscle regeneration in Duchenne muscular dystrophy. Am J Pathol 2016, 186:1302-1312

50. Braga TT, Agudelo JS, Camara NO: Macrophages during the fibrotic process: M2 as friend and foe. Front Immunol 2015, 6:602

51. Tidball JG, Villalta SA: Regulatory interactions between muscle and the immune system during muscle regeneration. Am J Physiol Regul Integr Comp Physiol 2010, 298:R1173-R1187

52. Chazaud B: Inflammation and skeletal muscle regeneration: leave it to the macrophages! Trends Immunol 2020, 41:481-492

53. Chen YW, Nagaraju K, Bakay M, McIntyre O, Rawat R, Shi R, Hoffman EP: Early onset of inflammation and later involvement of
TGFbeta in Duchenne muscular dystrophy. Neurology 2005, 65: 826-834

54. Kim HK, Merrow AC, Shiraj S, Wong BL, Horn PS, Laor T: Analysis of fatty infiltration and inflammation of the pelvic and thigh muscles in boys with Duchenne muscular dystrophy (DMD): grading of disease involvement on MR imaging and correlation with clinical assessments. Pediatr Radiol 2013, 43: $1327-1335$

55. Mavrogeni S, Papavasiliou A, Spargias K, Constandoulakis $\mathrm{P}$, Papadopoulos G, Karanasios E, Georgakopoulos D, Kolovou G, Demerouti E, Polymeros S, Kaklamanis L, Magoutas A, Papadopoulou E, Markussis V, Cokkinos DV: Myocardial inflammation in Duchenne muscular dystrophy as a precipitating factor for heart failure: a prospective study. BMC Neurol 2010, 10:33

56. Preuße C, von Moers A, Kölbel H, Pehl D, Goebel HH, Schara U, Stenzel W: Inflammation-induced fibrosis in skeletal muscle of female carriers of Duchenne muscular dystrophy. Neuromuscul Disord 2019, 29:487-496 